\title{
Mesenchymal Stromal Cells in Viral Infections: Implications for COVID-19
}

\author{
José Lucas Martins Rocha ${ }^{1,2}$ - Waldir César Ferreira de Oliveira ${ }^{1,3}$ • Nádia Cássia Noronha ${ }^{1,3}$. \\ Natalia Cristine Dias dos Santos ${ }^{1,3}$. Dimas Tadeu Covas ${ }^{1} \cdot$ Virgínia Picanço-Castro ${ }^{1} \cdot$ Kamilla Swiech $^{1,4}$. \\ Kelen Cristina Ribeiro Malmegrim ${ }^{1,4}$ (D)
}

Published online: 7 September 2020

(C) Springer Science+Business Media, LLC, part of Springer Nature 2020

\begin{abstract}
Mesenchymal stromal cells (MSCs) constitute a heterogeneous population of stromal cells with immunomodulatory and regenerative properties that support their therapeutic use. MSCs isolated from many tissue sources replicate vigorously in vitro and maintain their main biological properties allowing their widespread clinical application. To date, most MSC-based preclinical and clinical trials targeted immune-mediated and inflammatory diseases. Nevertheless, MSCs have antiviral properties and have been used in the treatment of various viral infections in the last years. Here, we revised in detail the biological properties of MSCs and their preclinical and clinical applications in viral diseases, including the disease caused by the severe acute respiratory syndromecoronavirus-2 (SARS-CoV-2) infection (COVID-19). Notably, rapidly increasing numbers of MSC-based therapies for COVID19 have recently been reported. MSCs are theoretically capable of reducing inflammation and promote lung regeneration in severe COVID-19 patients. We critically discuss the rationale, advantages and disadvantages of MSC-based therapies for viral infections and also specifically for COVID-19 and point out some directions in this field. Finally, we argue that MSC-based therapy may be a promising therapeutic strategy for severe COVID-19 and other emergent respiratory tract viral infections, beyond the viral infection diseases in which MSCs have already been clinically applied.
\end{abstract}

Keywords Mesenchymal stromal cells $\cdot$ Viral infections · COVID-19 $\cdot$ Immunomodulation $\cdot$ SARS-CoV-2 $\cdot$ Cell therapy $\cdot$ Viral diseases $\cdot$ Acute respiratory distress syndrome

\section{Biological Properties of MSCs}

Mesenchymal Stromal Cells (MSCs) are a multipotent progenitor cells that have been largely used for multiple clinical applications, including autoimmune and inflammatory

This article belongs to the Topical Collection: Special Issue on COVID19 Pandemic and Stem Cells

Guest Editor: Mariusz Z. Ratajczak

Electronic supplementary material The online version of this article (https://doi.org/10.1007/s12015-020-10032-7) contains supplementary material, which is available to authorized users.

Kelen Cristina Ribeiro Malmegrim

kelenfarias@fcfrp.usp.br

1 Center for Cell-based Therapy, Regional Blood Center of Ribeirão Preto, Ribeirão Preto Medical School, University of São Paulo, Ribeirão Preto, Brazil

2 Basic and Applied Immunology Program, Department of Biochemistry and Immunology, Ribeirão Preto Medical School, University of São Paulo, Ribeirão Preto, Brazil diseases, allotransplant rejection, spinal cord injuries, myocardial infarction, degenerative disorders, bone diseases, severe pneumonia, extensive burns and severe chronic wounds [1-4]. Nowadays, these cells are even more in demand for pre-clinical and clinical trials since emerging viral
3 Bioscience and Biotecnology Program, Department of Clinical Analysis, Toxicology and Food Science, School of Pharmaceutical Sciences of Ribeirão Preto, University of São Paulo, Ribeirão Preto, São Paulo, Brazil

4 School of Pharmaceutical Sciences of Ribeirão Preto, University of São Paulo, Av. do Café s/n, Ribeirão Preto 14040-903, São Paulo, Brazil 
infections are severely affecting people's health around the world [5].

Originally, Friedenstein and co-workers (1970) described MSCs as a "colony forming unit-fibroblast" present in stroma of rodent's bone marrow which could promote ectopic boneformation and present self-renewal capacity $[6,7]$. Many decades of studies have demonstrated that MSCs are present in various tissues in the body [7, 8] and share common biological properties [3, 9, 10].

Currently, it is possible to isolate MSCs from several human tissues, such as bone marrow, adipose tissue, dental pulp and even embryonic appendixes (e.g. umbilical cord, placenta, Wharton's jelly) for expansion and application in MSC-based therapies $[11,12]$. The International Society of Cell Therapy (ISCT) has established a universal criteria for MSC definition, thereby MSCs must display plastic-adherence capacity, fibroblastic spindle-shape morphology in standard culture media, surface expression of CD90, CD73, CD105 and absence of CD11b, CD34, CD45, HLA-DR, and in vitro differentiation potential for osteogenesis, chondrogenesis and adipogenesis [13]. Altogether, these criteria ensure authenticity of "MSC status".

\section{Immunomodulatory Properties of MSCs}

MSCs are able to suppress proliferation and modulate functions of both innate and adaptive immune cells [10]. Proinflammatory cytokines, such as IL-1 $\beta$, IL-2, IL-6, IL-8, IL-17, IFN- $\gamma$ and TNF- $\alpha$, signal through their receptors in MSC surface and stimulate biosynthesis of IL-10, TGF- $\beta$, TSG-6, LIF, HGF and expression of heme oxygenase-1 (HO-1), superoxide dismutase (SOD), cyclooxygenase-2 (COX-2), prostaglandin-E2 (PGE2), nitric oxide synthase (iNOS, produced by murine cells) and indoleamine-pyrrole 2,3-dioxygenase (IDO), produced by human cells [14, 15]. These molecules mediate the immunomodulatory and immunosuppressive properties of MSCs (Fig. 1) [10].

In addition, MSCs promote generation and expansion of regulatory immune cell subsets, such as $\mathrm{CD} 4^{+} \mathrm{CD} 25^{+} \mathrm{FOXP} 3^{+}$ T cells, CD ${ }^{+} \mathrm{CD} 28^{-} \mathrm{T}$ cells, and IL-10 producing B cells, IL10-producing dendritic cells (DC) [9, 10, 14-16]. In turn, these immunoregulatory cells amplify and reinforce the immunosuppressive effects of MSCs.

The PGE2 synthesis is mediated by COX-2, which can be induced in MSCs by the presence of inflammatory stimuli [17]. Bone marrow derived-MSCs (BM-MSCs) activated by TNF- $\alpha$ and/or lipopolysaccharide (LPS) are capable of releasing PGE2 into their microenvironment and induce macrophage production of IL-10 in vitro and in vivo, reprograming macrophages into an anti-inflammatory profile (Fig. 1), as well as improving the survival in murine models of sepsis [9, 15, 18]. Moreover, Hyvärinen and colleagues (2018) observed that the MSC secretomes from co-cultures with activated-macrophages have significantly enhanced PGE2 levels and diminished IL-22 and IL-23 levels [19].

According to Cheung et al. (2019), efferocyted MSCs induce COX-2/PGE2 expression in monocytes, thereafter, upregulating other immunosuppressive molecules such as IDO, programmed death-ligand 1 (PD-L1) and IL-10 through the activation of cAMP and PKA pathways [20]. In contrast, another study has reported macrophage polarization (from an inflammatory M1 phenotype into an anti-inflammatory M2 phenotype) by human placental-derived MSCs (P-MSC), via glucocorticoid and progesterone receptor signaling [21, 22]. These findings suggest that MSCs can elicit M2-like macrophages and monocytes through more than a single mechanism, and COX-2/PGE2 synthesis is involved in the differential expression of anti-inflammatory molecules by myeloid cells (Fig. 1) [23].

The immunosuppressive effects of IDO concerns the conversion of tryptophan in kynurenine (Kyn) [24]. Tryptophan is an essential amino acid to metabolism and thus, immune cell growth [24, 25]. Thereby, tryptophan depletion mediated by IDO leads to a surrounding collection of its catabolite, which seems to be especially toxic for T cells (Fig. 1) [24, 25]. Hence, new data revealed that the COX-2 inhibition was sufficient to prevent the induction of IDO in different IDOexpressing cells $[20,26]$. Somehow, regulation of IDO and COX-2 in MSCs appears to be linked as well. It is strengthened by the fact that COX-2 gene-transfected MSC not only overexpressed COX-2 but augmented IDO1 and biosynthesis of other anti-inflammatory molecules [27].

Importantly, IDO-expressing MSC also induces monocytes to differentiate into M2-like macrophages [9]. In addition, IDO and PGE2 exert a cooperative inhibition of NK and Th17 cells, B cell inhibition via cell cycle arrest, decreased immunoglobulin (IgM, IgG and IgA) production (Fig. 1) and diminished expression of CXCR4, CXCR5, and CXCR7 in the same cells [9, 10, 15].

Interestingly, studies have shown that IDO can regulate TSG-6 expression via kynurenic acid [28]. Kyn activates the aryl hydrocarbon receptor in human MSC leading to TSG-6 transcription [9]. This molecule is produced by TNFstimulated MSCs and attenuate inflammation by inducing macrophages to adopt an $\operatorname{Arg} 1^{+} \mathrm{CHIL} 3^{+}$phenotype (Fig. 1). It is attributed to the inhibition of TLR2/MYD88 association and subsequently impairing NF-kB-dependent activation of inflammatory genes transcription [29].

In addition, IL-10 and TSG-6 also suppress JAK1/STAT3 and MAPK/NF-kB signaling pathways during LPS-induced maturation of immature DC (Fig. 1) [30]. Another aspect is that TSG-6 is able to bind membrane CD44 in innate immune cells and inhibit migration steps, prevent costimulatory signals (e.g. CD80, CD86) and antigen presentation [31-33].

Several studies demonstrated that HGF, TGF- $\beta$, IL-10 and Kyn are involved in the MSC immunosuppressive activity 


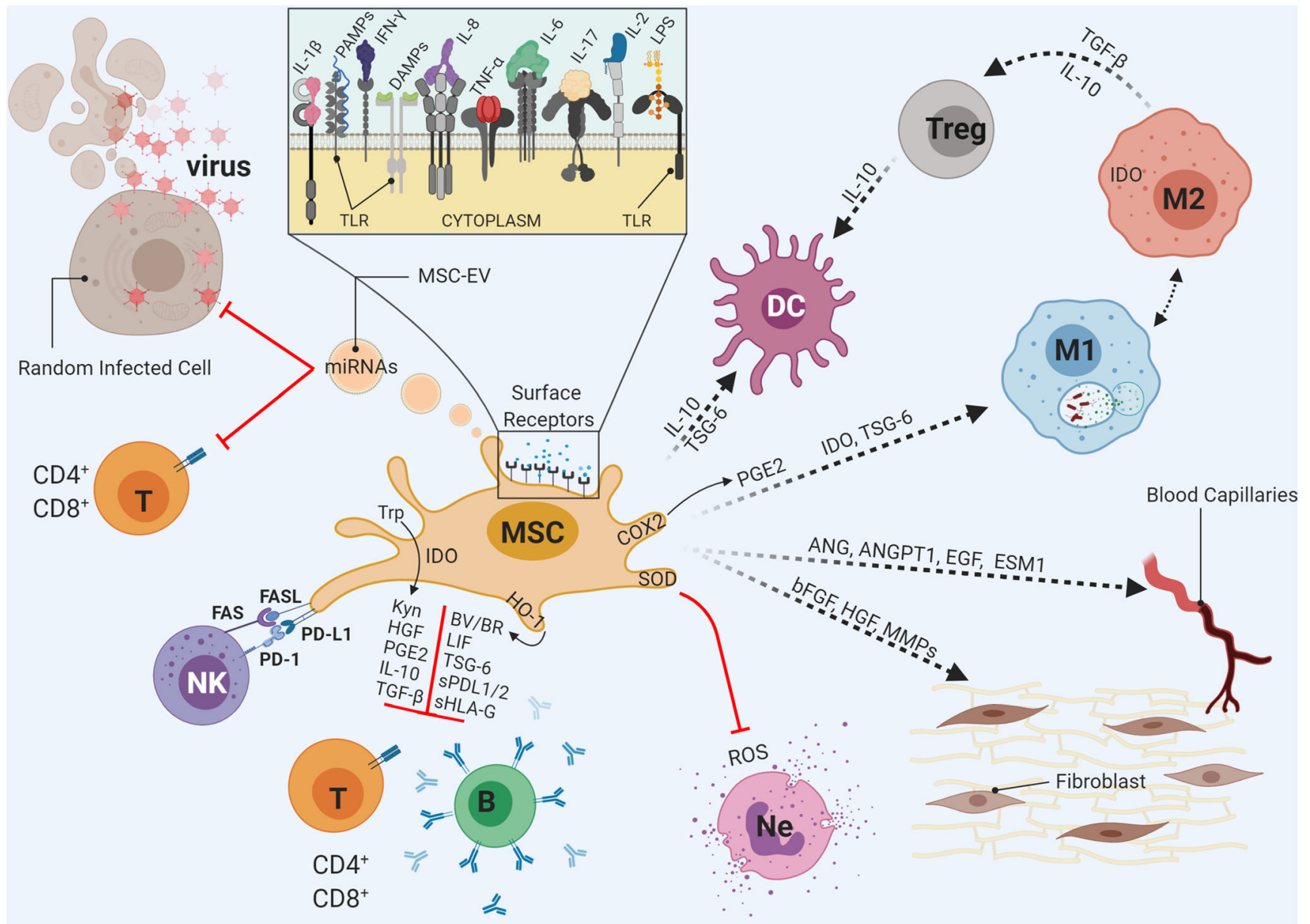

Fig. 1 Overall biological properties of MSCs. A. MSCs is able to detect inflammatory stimuli through several surface receptors (receptor of PAMPs and DAMPs receptors, TLRs, cytokine receptors, among others) and trigger inhibitory responses in immune system cells via enzymatic machinery upregulation (SOD, COX2, IDO, HO), soluble factors secretion (anti-inflammatory cytokines, such as IL-10, TGF- $\beta$; or other inhibitory molecules, such as PGE2, TSG-6, HLA-G, LIF), inhibitory (PD-1/PDL-1) or apoptotic (FAS-FASL) surface ligand expression, and miRNA enriched MSC-EV release. Concurrently, MSCs help immune cells to resist against viral infections (for example, via miRNAs) and regenerate damaged tissue via secretion of proangiogenic factors (such as ANG, ANGPT1, EGF, ESM1) and extracellular matrix regulatory factors (for example bFGF, HGF, MMPs). Abbreviations: ANG, Angiogenin; ANGPT1, Angiopoietin 1; bFGF, Basic fibroblast growth factor; BV/BR, Biliverdin and Bilirubin;

in vitro $[34,35]$ (Fig. 1). MSC stimulation with IFN- $\gamma$ leads to increased HGF, TGF- $\beta$ and IDO expression, and improved MSC-mediated allo-suppression in mixed lymphocytes reactions (MLRs), whereas, MSCs also can elicit $\mathrm{CD}^{+} \mathrm{CD} 25^{+} \mathrm{FoxP}^{+}{ }^{+} \mathrm{T}$ cells via TGF- $\beta$, IL-10 and PGE2 secretion in MLRs [15, 34-37].

Moreover, with the production of HGF, TGF- $\beta$, IL-10, and PGE2, MSCs also secrete IL-4 and LIF (Fig. 1) [10, 14]. All those factors together frame an anti-inflammatory compound which inhibits activation, proliferation and differentiation of
COX2, Cyclooxygenase-2; DAMPs, Damage-associated molecular pattern; EGF, Epidermal growth factor; ESM1, Endothelial Cell Specific Molecule 1; FAS/FASL, apoptosis antigen 1 receptor and ligand; HGF, Hepatocyte growth factor; HLA-G, Human leukocyte antigen G; HO-1, Heme oxygenase 1; IDO, Indoleamine 2,3-dioxygenase; ISGs, Interferon-stimulated genes; Kyn, Kynurenin; LIF, Leukemia inhibitory factor; LPS, Lipopolysaccharide; miRNAs, micro RNA; MMPs, Matrix metalloproteinases; MSC-EV, Extracellular vesicles from MSC; PAMPs, Pathogen-associated molecular pattern; PGE2, Prostaglandin E2; PD-1/PD-L1, Programmed death receptor and ligand; ROS, Reactive oxygen species; SOD, Superoxide dismutase; sHLA-G, Soluble human leukocyte antigen G; sPD-L1/2, Soluble Programmed death ligands 1 and 2 ; TGF- $\beta$, Transforming growth factor $\beta$; TLR, Toll-like receptor; TNF- $\alpha$, Tumor necrosis factor $\alpha$; Trp, Tryptophan; TSG-6, TNFstimulated gene 6

allogeneic T cells into Th1, Th17 subsets, and stimulate their differentiation into Th2 and Treg cells [10, 14, 37].

Among MSC surface molecules, there are inhibitory proteins such as B7-H4, PD-L1/2, FASL, and HLA-G1/3, and intercellular adhesion molecules like CD54 and VCAM-1 [10, 38]. Among these, two main molecules are involved in MSC cell-cell dependent immunosuppressive properties, PD-L1 and FASL (Fig. 1). For example, IFN $\gamma$-primed MSCs upregulate surface PD-L1, which binds PD-1 (receptor) and promotes an inhibitory stimulus to already activated-T cells [9]. 
Similarly, long-lasting FASL interactions enable MSCs to induce T cell apoptosis [39].

Furthermore, MSCs secrete non-classical histocompatibility complexes, sHLA-G5/7 (Fig. 1). sHLA-G5 was reported to contribute to MSC tolerogenic behavior by inhibiting allogenic peripheral blood mononuclear cells (PBMCs) and NK cell mediated-cytolytic activity in vitro $[8,38,40,41]$. The role of the $\mathrm{G} 7$ isoform has yet to be enlightened [42]. In agreement, Chen and colleagues (2017) cocultured umbilical cord derived-MSCs (UC-MSC) with PBMCs from systemic lupus erythematosus (SLE) patients and observed increased Treg cell frequency, which was partially abolished by an HLA-G blockage-antibody. The same study demonstrated increased expression of ILT2 receptor on $\mathrm{CD}^{+} \mathrm{T}$ cells, indicating that UC-MSC can possibly augment Treg cell frequency via sHLA-G/ILT2 interactions [43].

Through a lesser known mechanism, HO-1 enzyme is related to MSC homeostasis, due to its catabolic action on heme group from hemoglobin, forming by-products such as free iron ions $\left(\mathrm{Fe}^{2+}\right)$, biliverdin and carbon monoxide (CO) (Fig. 1). HO-1 by-products seem to display anti-inflammatory, antioxidant and antiapoptotic actions $[44,45]$.

Another mechanism that contributes to avoiding oxidative stress of MSCs is their expression of superoxide dismutase (SOD), which disrupts superoxide anion in hydrogen peroxide and free oxygen. In addition, SOD expression may also act preventing surrounding tissue destruction due to reactive oxygen species from neutrophils and M1-type macrophages (Fig. 1) [46]. Moreover, during tissue injury situations, where there is plenty of ATP, the CD73 molecule expressed in MSC membrane surface acts converting ATP into adenosine. The adenosine, in turn, binds to A2a receptors and leads to decreased $\mathrm{T}$ cell proliferation [47].

MSCs from all sources express transcripts of Toll-like receptors (TLRs), which allow them to recognize the pathogens, including viruses [9, 48, 49] (Fig. 1). For example, MSCs derived from adipose tissue express TLR2, TLR3, TLR4, and TLR9 at transcriptional and protein levels [9, 48, 49]. Thus, MSCs are provided with the TLRs machinery to activate both the inflammatory NF- $\mathrm{kB}$ pathway and interferon regulatory factor, which are fundamental to fight viral infections.

MSC-secreted extracellular vesicles (MSC-EV) have been gradually acknowledged as a multicomplex paracrine factor which carry various biomolecules (e.g. miRNAs). Categorically, MSC-EV are portrayed as exosomes and microvesicles [50, 51]. At the moment, some non-coding miRNAs such as Let-7, miR-34a, miR-146a and miR-200b/ $\mathrm{c}$ were identified by their interference in metabolic pathways of proinflammatory mediators (Fig. 1) [52, 53].

Let-7 has been implicated in the repression of posttranscriptional control of IL-6 synthesis and downregulates TLR4 signaling [54-56]. Additionally, miR-34a and miR-146 appear to play a pivotal role in regulation of NF-kB cascade, probably targeting upstream elements during $\mathrm{T}$ cell activation [57, 58]. Finally, miR-200b/c seems to reduce complementdependent cytolysis, occasioned by C5b-9 binding, whereas inhibition of miR-200c enhanced MSC death [59]. These findings suggest that miRNAs from MSC-EV may exert further antiinflammatory and cytoprotective effects on damaged tissues.

MSC secretome helps the organism to promote tissue repair of damaged areas via secretion of proangiogenic, antiapoptotic and antifibrotic factors [12, 60]. Frequently, after severe inflammation and prolonged tissue destruction, the input of nutrients and oxygen is impaired, resulting in a serious organic ischemia. Thus, neovessels formation is essential to raise blood perfusion, therewith, maximize the number of viable resident cells, finally restoring tissue function and preventing fibrosis [12]. Among the proangiogenic/ antiapoptotic factors secreted by MSC are ANG, ANGPT1, bFGF, CXCL12, EGF, ESM1, IGF-1, IL-6, JAG1, LIF, MCP-1, MMP-1, PDGF, PIGF, PTN, STC1, TGF- $\beta$, and VEGF (Fig. 1) [12, 16, 61, 62].

Another MSC's biological property is their "anti-scarring" effect. MSCs, as well as the recruited macrophages, have been shown to contribute to tissue healing, expressing mediators that decrease fibrotic processes (Fig. 1) [63, 64]. This antifibrotic property is mediated by the secretion of plasmindependent proteinases and others MMPs (involved in all stages of angiogenic processes), which mediate the ECM remodeling. In addition, MSCs express and/or secrete ADAMTS2, bFGF, COL15A1, COL16A2, COL18A1, COL5A3, DPT, ELN, FBLN2, FBLN5, FMOD, HAPLN1, HGF, HTRA1, LOX, MFAP2/4, NID2, TIMP2, and possibly adrenomedullin [12, 16, 64, 65]. Besides, this anti-fibrotic property allows MSCs to control organization of collagen, fibronectin and elastin fibrils, likewise the balance of fibroblast activity $[12,66]$.

\section{Antiviral Properties of MSCs}

MSCs are typically resistant to viral infections when compared to more differentiated cells. Such an ability is given by the presence of IFN-stimulated genes (ISG) that can target at many stages during viral cycle, thereby avoiding viruses to overpass cell membrane, blocking endocytic route, mRNA transcription, nuclear import of mRNAs, genome integration/amplification, protein translation, virus assembly and release (Fig. 2) [5, 67, 68].

Among the ISGs expressed in MSCs, PMAIP1, ISG15, IFI6, IFITM, SAT1, p21/CDKN1A, SERPINE1 and CCL2 stand out $[5,69]$. These ISG act by limiting many viral infections in vitro, such as dengue, ebola, SARS, and influenza A viruses [67]. To demonstrate the importance of some MSC derived-ISGs, $\mathrm{Wu}$ and co-workers (2018) silenced p21/ CDKN1A expression, resulting in increased MSC susceptibility to chikungunya virus infection. Although, upon silencing 


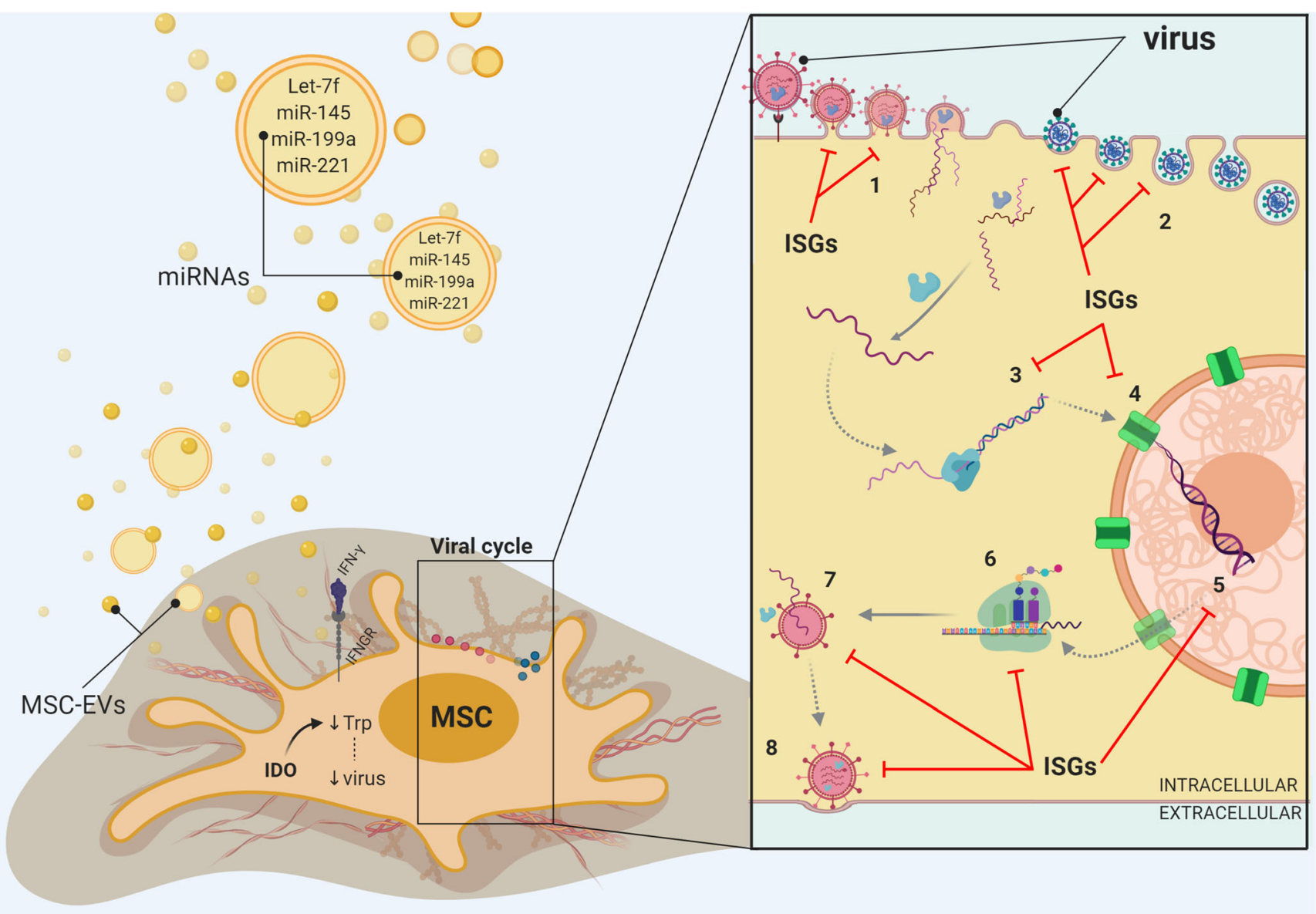

Fig. 2 Antiviral properties of MSCs. MSCs display intrinsic viral resistance via ISGs, by blocking: (1) viral entry through viral capsidcell membrane fusion (2) viral entry through endocytic route (3) mRNA reverse-transcription, (4) nuclei import, (5) genome integration/ amplification into host's DNA, (6) protein translation, (7) virus assembly, and (8) viral egress. In addition, IFN $\gamma$-stimulated MSCs express IDO, reducing the content of intracellular Trp that might lead to a decrease in

IFITM3, MSCs became more susceptible to yellow fever virus and zika virus infection [5, 69].

Khoury and collaborators set up a list of ISGs constitutively expressed by human MSC, and configured by IFITM1, IFI6, CCL2, ISG15, SAT1, and PMAIP1. In the presence of IFN- $\gamma$, non-constitutive ISGs are induced, including MT1G, CD74, SERPING1, IFNAR2, and MT1X [5]. Besides the high expression of constitutive ISGs by MSCs, the upregulation of non-constitutive ISGs upon MSC activation/priming, represents an "adjustment ability" to enhance antiviral capacity. This MSC feature can be beneficial in the context of respiratory tract infections [5].

One of the antiviral ISGs identified by Kane and coworkers (2016) was IDO (Fig. 2). They observed that IDOexpressing MSC, which have been in vitro primed with IFN- $\gamma$, reduced HIV-1/2 virion yield. The authors hypothesized that this effect might be related to tryptophan depletion, which limits emergent viral protein biosynthesis [70]. IDO viral production. MSCs also secretes extracellular vesicles bearing antiviral microRNAs to the microenvironment. Abbreviations: IDO, Indoleamine 2,3-dioxygenase; IFN- $\gamma$, Interferon gamma; IFNGR, Interferon gamma receptor; ISGs, Interferon-stimulated genes; miRNAs, Micro RNAs; MSC-EV, Extracellular vesicles from MSC; Trp, Tryptophan

nutrient-deprivation is a useful antiviral MSC strategy and this effect has been observed against measles virus, cytomegalovirus, herpes simplex virus-1 and HBV [70-73]. As well as the immunomodulatory function of IDO, it also seems to be a fundamental antiviral molecule secreted by MSCs.

Another described antiviral mechanism of MSCs is the release of non-coding miRNAs. Some miRNAs were described as having potent antiviral activity by targeting viral replication (Fig. 1). Qian et al. (2016) showed that MSC antiviral activity against hepatitis $\mathrm{C}$ virus (HCV) is mainly conferred by Let-7f, miR-145, miR-199a, and miR-221 present in MSC-derived extracellular vesicles (EVs). Therefore, MSC-EVs could be an advantageous product for anti-HCV therapy [74] (Fig. 2).

\section{Physiological Properties of MSCs}

In homeostasis, the main physiological roles of MSCs are related to two wider ranging abilities known as "cell 
replacement" and "cell empowerment" [2, 8]. "Cell replacement" corresponds to the physiological tissue repair ability through cellular expansion and differentiation upon demand or injuries $[2,8]$. In contrast, "cell empowerment" is about the influence exerted by MSC on their tissue microenvironment through secretion of soluble bioactive molecules and/or exosomes, which can be dispersed throughout the region $[8$, $75,76]$.

Pericytes are an important subpopulation of MSCs. Pericytes have contractile capacity due to their cytoplasmic extension that surrounds the abluminal wall of the endothelial cell lining the capillaries and venules throughout the body. These cells have phenotypic signatures like MSCs and exhibit typical markers, such as PDGF $\beta$ and NG2 [77]. At first, it was believed that pericytes had a vessel stabilization function. However, recent studies show that they exert other important functions such as controlling vascular permeability and immunological surveillance [78].

As soon as an infection occurs, PAMPs and DAMPs from apoptotic cells come into contact with tissue-resident MSCs that express Toll-like receptors (such as TLR4 and TLR6), which allow them to recognize the pathogens. As vigilant cells, pericytes also have Toll-like receptors [78] and can increase the permeability of the endothelium as soon as they detect molecules of the invading agent or pro-inflammatory molecules, allowing immune cells such as neutrophils, monocytes, and dendritic cells, to perform diapedesis more quickly at the infected site.

Particularly in the lung, due to the direct contact with the alveolus, pericytes have important paracrine functions (Fig. 3A), such as endothelial activation, by modifying adhesion molecules and secreting chemotactic agents, as they are sensitive to the amplification of the inflammation site in case of epithelial barrier disruptions [77]. Pericytes are generally capable of promoting acute inflammatory responses when exposed to bronchoalveolar lavage fluid (BALF) [77]. Thus, when there are dysfunctions in the pericytes, the vascular permeability is increased [79].

In this scenario, MSCs play a fundamental role in the pathophysiology of viral infections. MSCs are able to communicate and modulate their microenvironment, maintaining tissue homeostasis [9]. Any tissue damage causes changes in the conformation of the extracellular matrix. MSCs are sensitive to pro-inflammatory signals and are able modulate the

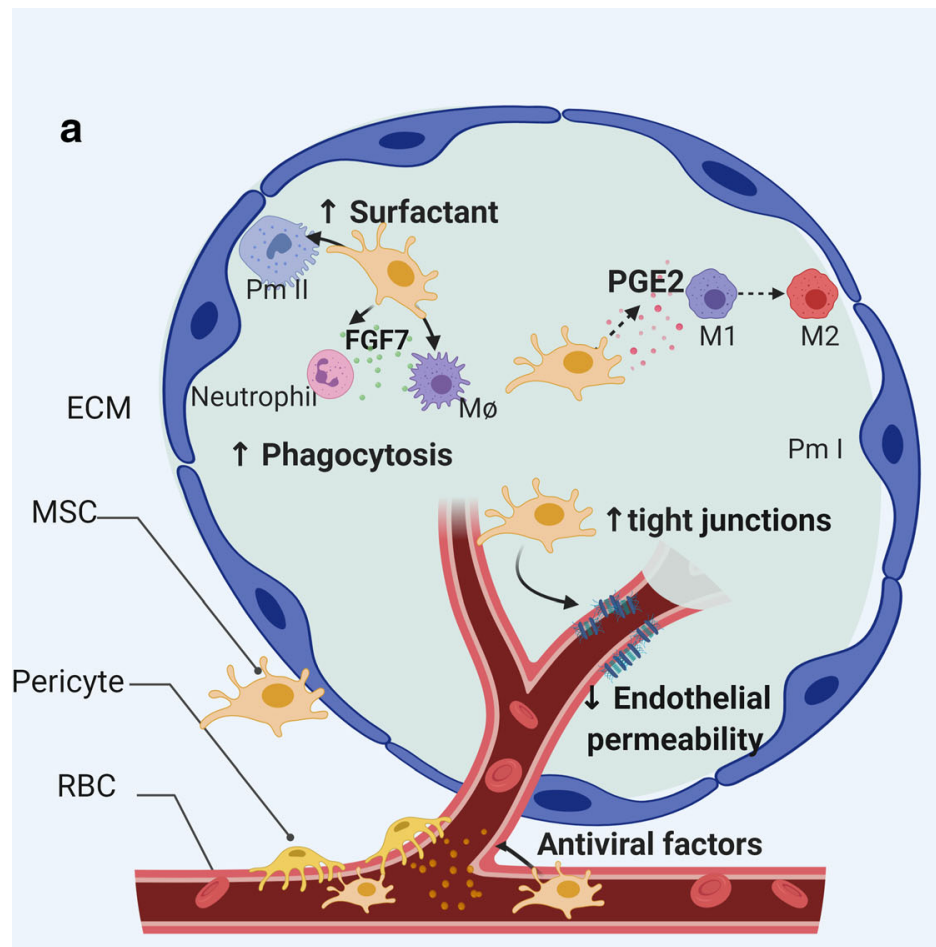

b
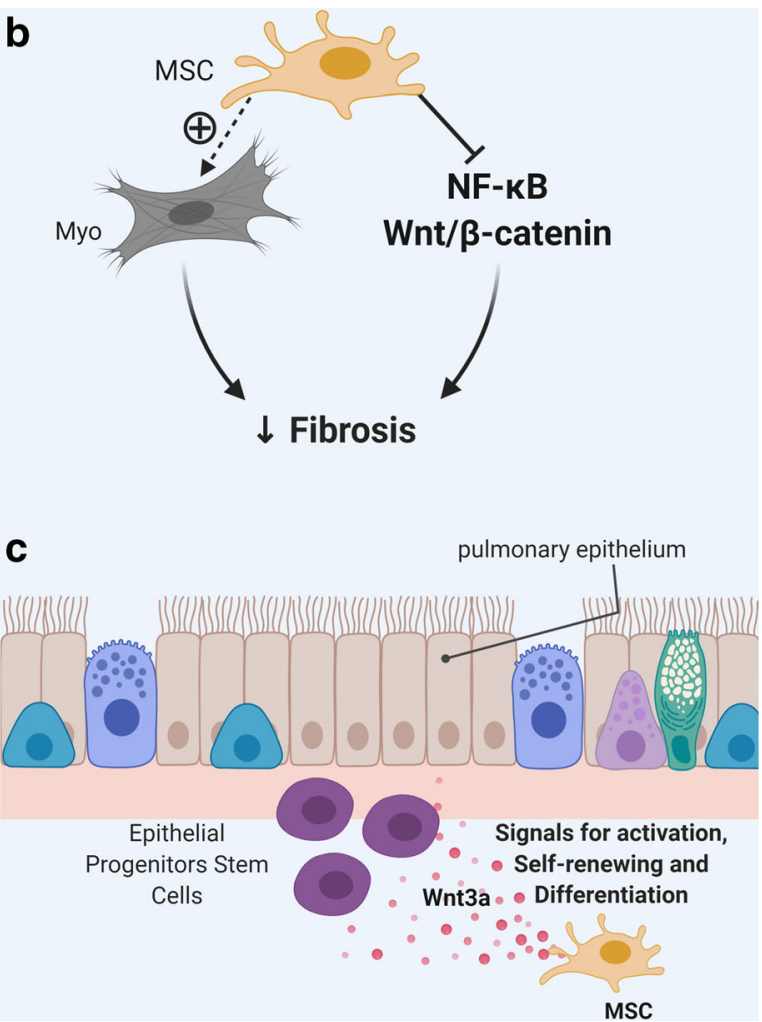

Fig. 3 Role of lung tissue-resident MSCs in viral infections. (a). Tissuespecific resident MSCs are capable of modulating their microenvironment by secreting antiviral factors for eventual viral infections; upregulating tight junction gene expression to reduce endothelial permeability; stimulating surfactant production by type II pneumocytes; and modulating the proliferation, differentiation and functions of immune system cells. RBC: red blood cells; Myo: myofibrolasts; Pm I/II:

pneumocytes type I/II; ECM: extracellular matrix; MSC: mesenchymal stem/stromal cell. (b). Fibrosis modulation by blocking the NF- $\mathrm{kB}$ and $\mathrm{Wnt} / \beta$ catenin complexes and upregulation of genes related to myofibroblast differentiation. (c). Trophic factors/signals secreted by tissue-resident MSCs induces activation, self-renewal and differentiation of epithelial progenitor cells in order to renew the pulmonary epithelium 
inflammatory and immune response in different ways (Fig. 3A). For example, MSCs can reduce oxidative stress, which is effective against coxsackievirus-B3 [80]. As a stromal pulmonary component, in addition to supporting the maintenance of respiratory system progenitor cells, MSCs also provide signals for activation, self-renewal and differentiation of submucosal duct progenitor cells, bronchioalveolar stem cells, alveolar progenitor cells and some types of epithelial progenitor cells [81]. The main homeostatic role of MSCs is the paracrine production of trophic factors and bioactive molecules capable of coordinating the microenvironment in which they are inserted [82].

\section{MSC Therapy in Viral Infections: Preclinical and Clinical Applications}

Some pre-clinical studies have indicated beneficial effects of MSCs in different viral infections [83]. Chan and collaborators demonstrated that influenza $\mathrm{A} / \mathrm{H} 5 \mathrm{~N} 1$ infection impaired alveolar fluid clearance (AFC) and increased alveolar protein permeability (APP) in vitro in human alveolar epithelial cells (AEC), associated with acute lung injury [84]. This effect was prevented or reduced by human BM-MSCs, partially via angiopoietin-1 (Ang1) and keratinocyte growth factor (KGF) secretion in the co-culture assay. MSC treatment at day 5 postinfection increased survival and body weight, improved lung pathology and histopathology scores in aged $\mathrm{A} / \mathrm{H} 5 \mathrm{~N} 1-$ infected mice [84].

Superior results were demonstrated using UC-MSCs that restored more effectively the AFC and APP in A(H5N1)-infected AECs, partly through secretion of high amounts of Ang1 and HGF, and also exhibited a greater ability to reduce A/H5N1-induced downregulation of ion transporters in vitro. These effects have also been observed using conditioned medium and exosomes of UC-MSCs. Notably, UC-MSCs treatment slightly improved survival of A/H5N1-infected mice and significantly improved fluid clearance in the alveolar airspace, compared to BM-MSCs and controls [85].

In addition, murine BM-MSC infusions also prevented liver inflammation and injury when injected $24 \mathrm{~h}$ prior to hepatitis B virus (HBV) inoculation in mice. NK cells have been reported to contribute to the pathogenesis of liver injury and inflammation. MSCs infusions decreased activating receptor NKG2D expression in NK cells in the liver [86].

To date, safety concerns have limited use of MSC-based therapy for viral diseases [5]. Nevertheless, MSC infusions have displayed benefits in the treatment of human respiratory tract diseases from both infectious and noninfectious causes. Despite limited published clinical data, the clinical trials conducted so far have reported that MSC application in viral diseases are safe $[87,88]$.
Simonson et al. described beneficial effects of BM-MSC therapy in two patients with severe refractory acute respiratory distress syndrome (ARDS) of different underlying etiologies. The MSCs infusion $\left(2 \times 10^{6}\right.$ cells per kilogram of recipient body weight) has decreased many pulmonary and systemic markers of inflammation and improved lung function evidenced by decreased pulmonary infiltrates $24 \mathrm{~h}$ after treatment. BALF albumin levels, a marker of alveolar-capillary barrier integrity and permeability, was also reduced to an undetectable level also $24 \mathrm{~h}$ post-MSC infusion. Finally, reduced IL-6 levels in BALF, and IL- 8 and IFN- $\gamma$ levels in plasma, were observed in the first days following MSC treatment of the influenza $\mathrm{A} / \mathrm{H} 1 \mathrm{~N} 1$ patient [89].

MSC-based therapy has also been performed in patients with hepatitis B virus-related liver cirrhosis (HBV-LC) [90]. A randomized trial revealed that autologous BM-MSCs infusions into the liver combined with antiviral treatment improved the liver function of patients with HBV-LC, compared to control group (antiviral alone). Infusions of MSCs have corrected Treg/Th17 cell imbalance associated with pathogenesis of HBV-LC, markedly increased Treg cells number in the first 12 weeks and significantly decreased Th17 cell frequency. A more pronounced reduction of IL-6, IL-17A, and TNF- $\alpha$ serum levels was observed in the treated group, compared to controls. Conversely, patients treated with MSCs had a significant increase of TGF- $\beta$ levels [90].

Similar results were obtained in the study conducted by Fang and collaborators using UC-MSC in patients with chronic hepatitis B-induced decompensated liver cirrhosis [91]. Fifty patients were treated with $4.0-4.5 \times 10^{8}$ cells intravenously in two doses on consecutive days. MSC-treated patients-treated group showed decreased inflammatory cytokine levels compared to control group, increased IL-10 levels and Treg cells, and remarkably improved liver function [91].

Treatment of patients with HBV-related acute-on-chronic liver failure (ACLF) with MSCs was also safe and effective. Treatment with $1 \times 10^{8}$ UC-MSCs enhanced both short-term and long-term general liver function [92].

Another relevant clinical trial showed that allogeneic BMMSCs (1.0-10 $\times 10^{5}$ cells $/ \mathrm{kg}$ infused weekly for 4 weeks) improved the 24-week survival rate of patients with HBV-ACLF in relation to the control group $(73.2 \%$ and $55.6 \%$, respectively), presumably due the improvement of liver function and decreased incidence of severe infections [93].

Finally, Zhang and colleagues (2013) assessed the safety and efficacy of MSC treatment in HIV-1-infected immune non-responders. Patients received three doses of UC-MSC $\left(0.5 \times 10^{6} / \mathrm{kg}\right.$ body weight i.v. with a month-long break between each dose). The results indicated UC-MSC therapy reduced inflammation and overactivation of the immune system, as well as enhanced the immune reconstitution, evidenced by significant reduction of activated $\mathrm{CD}^{+} \mathrm{T}$ cells and an increase in circulating CD $4^{+} \mathrm{T}$ cells [94]. 


\section{MSCs, SARS-CoV-2 and COVID-19: From the Role in Pathogenesis to Clinical Therapeutic Applications}

As previously described, MSCs can be found in the stroma of virtually any body tissue. Here, we will focus on the lung to describe the role of tissue-resident MSCs. The lung is one of the main immunological barriers against pathogens [78]. By modulating inflammatory mediators, lung-resident MSCs promote microvascular remodeling and cellular differentiation contributing to tissue repair and regeneration of this barrier [94].

In the lungs, resident MSCs are specifically located in the perivascular and exhibit surface markers similar to their bone marrow counterparts. Importantly, ex vivo lung-derived MSC have high expression of CD73 [94]. It has been suggested that CD73 signaling increases the expression of anti-inflammatory genes and reduce the expression of pro-inflammatory genes in macrophages [94].

For example, proteomic analysis revealed that bone marrow and lung derived-MSCs exhibit significant differences in the expression levels of markers such as CD9, CD29, 219 CD44, CD166, STRO-1, NG2, AQ5, HLA-1, $\alpha$-SMA, and HLA class I [95], suggesting that these cells differently change their expression profiles according to the tissue microenvironment. These dynamics of MSC proteomics and transcriptomics demonstrate that they are very sensitive to changes in the stroma milieu. Thus, characteristics of resident MSCs depends on the tissue and the microenvironment in which they are inserted [94]. According to microenvironmental changes, MSCs secrete soluble factors capable of modulating immune responses, cellular activation and differentiation.

When exposed to the BALF, lung-resident MSCs trigger a mechanism for the clearance of alveolar fluid by paracrine secretion of FGF7 (or KGF). The growth factor mediates the maintenance of apical membrane of epithelial cells, restoring the cellular sodium channels ( $\alpha \mathrm{E} 9 \mathrm{NaC}$ subunits), thereby normalizing the clearance of the alveolar fluid. When FGF7 was depleted, these effects were not observed ex vivo, confirming the MSC paracrine protective role [96].

In addition, lung-resident MSCs exhibit the transition epithelium-mesenchymal (SNA12, HGF, TGF- $\beta 2$ and 3, TCF4 and CDH2) proteomic and transcriptomic profiles, which are much more pronounced in lung-resident MSCs than in BM-MSCs. Therefore, lung-resident cells have upregulated $\mathrm{Wnt} / \beta$-catenin pathway and down-regulated NF-KB signaling (Fig. 3B). In the bleomycin-induced pulmonary model, it has been shown that inhibition of this pathway, decreased TNF- $\alpha$ production, therefore reducing fibrosis development [97].

Another mechanism of lung-resident MSCs is the expression of genes related to epithelial and myofibroblast differentiation, which consequently lead to fibrosis modulation [98, 99]. In fact, lung-resident MSCs exhibit genes particularly related to adherence and extracellular matrix formation, which allow for the correction of the structures of the lungs (thick and elastic layers) and proper physiological functioning of the organ [94].

In the context of respiratory viral infections, lung-resident MSCs are capable of immunomodulating a cytokine storm and controlling the fibrotic process by inhibiting the main pro-fibrotic pathway which is TGF- $\beta$ signaling. In addition, MSCs can increase Wnt3a expression thereby inducing stem cell proliferation (Fig. 3C) [100].

In an ARDS model, MSCs infused into the lungs promoted differentiation in pulmonary endothelial cells, and alveolar epithelial cells, increasing the secretion of alveolar surfactant [82]. In conclusion, tissue-resident MSCs play an important and complex role in regulating tissue responses to viral infections.

The novel coronavirus disease 2019, which is known as COVID-19 has become a global public health emergency. COVID-19 is characterized by an acute respiratory illness caused by a new coronavirus type named as "severe acute respiratory syndrome coronavirus 2" (SARS-CoV-2). The COVID-19 is clinically heterogeneous, patients may be asymptomatic or have light, moderated, severe or critical symptoms [101-104].

The pathogenesis of SARS-CoV-2 has been identified by the interaction and binding of the virus spike glycoprotein (SARS-CoV-2S) to the angiotensin-converting enzyme-related carboxypeptidase (ACE2) on the target cell surface, followed by activation of spike protein by the cellular transmembrane protease serine 2 (TMPRSS2) and virus enters the host cell [101, 105-107].

The ACE2 receptor is abundant in human cells, especially the alveolar type II cells (AT2) alveolar cells, heart, liver, kidneys and digestive tract organs (Fig. 4A and B). The expression of ACE2 by endothelial and smooth muscle cells allows the entry of the virus into the bloodstream to be easy and widespread [106]. Therefore, all tissues that express ACE2 may be a potential target of the SARS-CoV-2 [107]. The wide expression pattern of ACE2 explains why critically infected patients are affected not only by acute respiratory distress syndrome, but also by other complications, such as myocardial injury, arrhythmia, acute kidney injury, and shock and death due to multiple organ dysfunction syndromes [101].

In patients infected by SARS-CoV-2 there is high infiltration of leukocytes, intense inflammatory response that leads to increase in vascular permeability, and consequently edema in the lung microenvironment. These initial symptoms may evolve to the acute respiratory distress syndrome (ARDS) in severe or critical patients [108]. In this scenario, the lungs are not able to provide sufficient oxygen saturation to the alveolar cells, causing hypoxemia. This prevents the various organs and tissues from receiving adequate nutrition, resulting in general organ failure [108, 109]. 


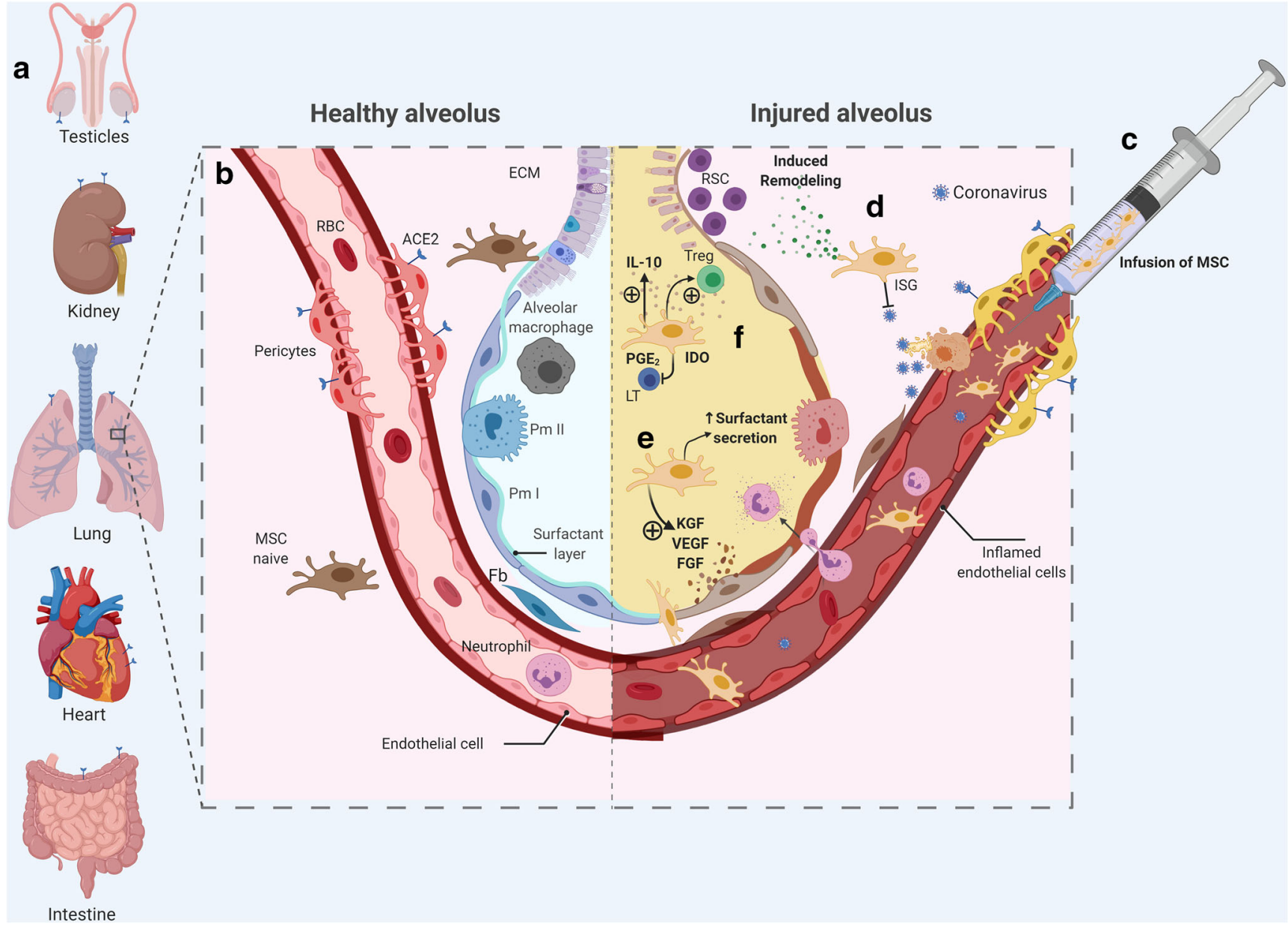

Fig. 4 Role of MSCs in SARS-CoV-2 infection and their possible therapeutic application in COVID-19. The figure illustrates the complex microenvironment of the alveolus, capillaries and extracellular matrix. (a). ACE2 can be expressed in cells of several organs, such as in the lungs, heart, testicles, kidneys, and intestine. This figure focus on the lungs. (b). Left side represents the alveolus/capillary system of a healthy individual in homeostatic condition, containing pericytes in the capillary abluminal membrane, tissue-resident mesenchymal stromal cells, preserved respiratory epithelium and healthy alveolar structures. Pericytes and endothelial cells also express ACE-2. (c). Right side represents the alveolus/capillary system of a patient with COVID-19. The Intravenous infusion of exogenous MSCs as a possible treatment for SARS-CoV-2 infection. MSCs migrate to the lungs and where they can exert their antiviral properties. (d). MSCs secrete ISGs that inhibit viral invasion of healthy cells and viral replication in infected cells. As

Severe patients with COVID-19 have predominantly cardiovascular complications. The distribution of ACE2 in the cells of the heart is still unclear [102]. ACE2 is the main pathway for ANGII metabolism, a peptide with multiple actions that promotes cardiovascular disease [110]. Besides degrading ANGII, ACE is also capable of generating Ang (1-7), which antagonizes the effect of ANGII in the heart. Therefore, in patients with underlying cardiovascular disease, the loss of ACE2 induced by SARS-CoV-2 is even worse. Loss of ACE2 may compromise cardiac function beyond viral infection [108]. signaling cells, MSCs also have the ability to signal to lung resident stem cells to renew the damaged epithelium. (e). In the alveolus, MSCs secrete growth factors which can induce lung cell subset proliferation, promote angiogenesis, prevent lung cell apoptosis, and also promote type surfactant production by type II pneumocytes. (f). In addition, MSCs exert immunomodulatory activity by secreting anti- inflammatory molecules (such as IL-10, PGE-2, IDO), promoting Treg cell expansion, and inhibiting effector immune cell functions). Thereby, MSCs could be able to control exacerbated inflammation in affected lung or other tissue microenvironment. RBC: Red blood cells; ACE2: Angiotensinconverting enzyme 2; Pm I/II: Pneumocytes type I/II; ECM: Extracellular Matrix; RSC: Respiratory Stem cells; ISG: Interferon stimulated genes; IDO: indoleamine 2,3-dioxygenase; LT: T lymphocyte; Treg: regulatory $\mathrm{T}$ lymphocyte

Currently, the treatment of patients with COVID-19 is challenging because there are not yet specific drugs or vaccines against SARS-CoV-2 available [159]. Therefore, the identification of safe and effective treatments for severely affected COVID-19 patient is critical for saving lives [101]. There are many immunotherapeutics and antiviral drugs being evaluated in clinical trials for patients with COVID-19, such as Remdesivir [106].

As earlier discussed, MSCs have natural abilities to deal with viral infections due to their powerful antiviral properties, as well as their powerful anti-inflammatory and 
immunomodulatory abilities that could to prevent or attenuate the cytokine storm in COVID-19 patients (Fig. 4C and D) [106, 107].

Pre-clinical studies (in vitro and animal models) have demonstrated that MSCs from different tissue sources have common biological properties [7, 14]. In the last years, the most used tissue sources were naturally chosen based on their availability, ethical and safety issues, and expansion potential $[3,4$, 10]. In addition, it has been demonstrated that the use of allogeneic MSCs is safe, as well as allow the availability of offthe-shelf MSC-products that can be rapidly applied into patients with acute diseases. In fact, MSCs derived from different sources have been used in the last years to treat patients with viral diseases [111] (Table 1, Table S1).

Preclinical models and clinical trials of patients with respiratory tract infections have paved the way for MSC-based therapy in SARS-CoV-2-related acute respiratory distress syndrome [83, 112]. Some research groups have already initiated clinical trials using MSC for treatment of critical COVID-19 [88] (Table 1, Table S1).

Recently, Leng and colleagues have investigated whether transplantation of MSCs could clinically improve 7 patients with COVID-19 pneumonia at the You'An Hospital in Beijing, China. Patients were treated with MSC infusions and were followed-up during 14 days for their clinical response and immunological profiling. The majority of patients had negative results for the SARS-CoV-2 nucleic acid test for one or two weeks after the MSC infusion, and general improvement was extraordinary for an elderly patient in critical condition after infection [107]. MSCs treatment also corrected lymphopenia, decreased C-reactive protein and proinflammatory cytokine TNF- $\alpha$ levels, enhanced IL-10 levels and dramatically increased regulatory $\mathrm{T}$ cells and DC populations. In addition, overactivated cytokine-secreting immune cells $\mathrm{CXCR} 3^{+} \mathrm{CD} 4^{+} \mathrm{T}$ cells, $\mathrm{CXCR} 3^{+} \mathrm{CD} 8^{+} \mathrm{T}$ cells, and $\mathrm{CXCR}^{+} \mathrm{NK}$ cells were absent after 3-6 days [107]. The results confirmed the therapeutic potential of MSCs to treat patients with COVID-19 (Fig. 4E and F) [105].

The therapeutic potential of Wharton Jelly's MSCs (hWJCs) for the treatment of COVID-19 was explored by Zhang et al. (2020) at Liaocheng People's Hospital in China. The researchers evaluated a critically ill patient, a 54-year-old man, diabetic and positive for COVID-19. Already with evidence of pneumonia in both lungs and unstable clinical conditions, the patient was treated with antiviral therapy. When the vital physical signs stabilized, the patient received an intravenous infusion of hWJCs. A few days after treatment, the patient showed a significant improvement in the clinical conditions, such as fever and shortness of breath disappeared, indicating a rapid recovery. Frequency of $\mathrm{CD}^{+} \mathrm{T}, \mathrm{CD} 4^{+} \mathrm{T}$ and $\mathrm{CD}^{+} \mathrm{T}$ cells increased and serum $\mathrm{C}$-reactive protein, IL6 and TNF- $\alpha$ levels were reduced. Six days after MSC treatment, the patient became negative for SARS-CoV-2.
Therefore, therapy based on the use of hWJCs may be effective in the treatment of patients with COVID-19 [104].

Altogether, based on these preliminary clinical reports, MSC-based therapy may be an alternative therapeutic approach for treatment of patients with COVID-19, alone or in combination with other treatment [103, 107].

\section{Ongoing MSC-Based Therapies for COVID-19 and Other Viral Diseases}

To identify the MSC-based therapies that are currently being applied for treatment of viral infections worldwide we used the Integrity Database (Clarivate Analytics). Figure 5, Table 1 and Table S1 demonstrate the analyses of 36 ongoing (recruiting phase) clinical trials for seven conditions related to viral infections in the last 9 years (searched on July 6th, 2020). There was an evident increase of ongoing clinical trials in 2020, compared with the past years (Fig. 5A). Twenty and nine ongoing MSC-based clinical to treat viral diseases registered were registered until July 6th, 2020. This increase is due to the treatment of emergent SARS-CoV-2 infection (COVID-19) with MSCs (Fig. 5B). In fact, 15 out of 36 clinical trials are treatments for COVID-19 (Fig. 5B). The viral diseases currently being treated with MSCs are Middle East Respiratory Syndrome (MERS), HIV infection, Hepatitis B, Respiratory Distress (from Acute Respiratory Distress Syndrome, ARDS), and Severe Acute Respiratory Syndrome (SARS-CoV-2/COVID-19) (Fig. 5B).

According to these data, most clinical trials are the early phase (phase I, I/II, II). However, there is one registered phase III clinical trial that uses the cellular product named Remestemcel-L. Remestemcel-L is a third-party, off-theshelf suspension of ex-vivo cultured adult human MSC intended for intravenous infusion. It was approved for use in Canada in May 2012 under the trade name Prochymal® by Osiris Therapeutics, for the management of refractory acute Graft-versus-Host Disease (aGvHD) in children who are unresponsive to systemic steroid therapies. Nowadays, Remestemcel-L is in phase III clinical study for the treatment of patients with moderate and severe acute respiratory distress syndrome (ARDS) caused by the coronavirus- 2 infection (COVID-19) (Fig. 5C).

Most MSC-based clinical trials for viral infections are randomized and open-label studies (Fig. 5D). The majority of the clinical studies use MSCs isolated from umbilical cord blood, followed by adipose tissue, as a tissue source. The most common biomarkers used in MSC-based clinical trials for infectious diseases are related to repress inflammation, such as proinflammatory cytokines, including tumor necrosis factor (TNF- $\alpha$ ), IL-6 and IL-10, and liver biomarkers for infections that target the liver (Fig. 5E). 
Table 1 MSC-based ongoing clinical trials for viral infection diseases (data from Integrity Clarivate database; searched on July 6th, 2020)

\begin{tabular}{l} 
Study Name \\
\hline Allogenic mesenchymal stem cells \\
in HIV infection: The \\
NCT02290041 study \\
Ongoing (11/2014) \\
Umbilical cord mesenchymal \\
stem cells in HIV infection: The \\
NCT01213186 study \\
Ongoing (5/2013) \\
Cord Blood-MSCs in cirrhosis/ \\
hepatitis B: The NCT04357600 \\
study \\
Ongoing (4/2020) \\
Human umbilical cord derived \\
mesenchymal stem cells in \\
HBV-related liver cirrhosis: \\
The NCT01728727 study \\
Ongoing (12/2012) \\
UC-MSC in acute-on-chronic \\
liver failure: The \\
NCT02812121 study \\
Ongoing (6/2016)
\end{tabular}

Hepatitis B

Condition
HIV infectio
HIV infectio
Hepatitis B

Hepatitis B

Phase I/II study; Open;

Randomized.

Hepatitis B
Phase II study; Open; Randomized.
Umbilical cord-derived mesenchymal stem cells in pneumonia/middle east respiratory syndrome coronavirus (MERS-CoV): The NCT04269525 study
Ongoing (2/2020)

AD-MSCs in viral
pneumonia/severe acute
respiratory syndrome
coronavirus 2 (SARS-CoV-2)
infection
(COVID-19)/respiratory
distress: The NCT04352803
study
Ongoing (4/2020)
CB-MSCs in respiratory distress:
The COVID-19;
NCT04416139 study
Ongoing (6/2020)
Mesenchymal stem cell in
COVID-19: The
NCT04392778 study
Ongoing (5/2020)

Pneumonia, viral Phase I study; Open.

$\begin{array}{lc}\begin{array}{l}\text { Middle East } \\ \text { respiratory } \\ \text { syndrome } \\ \text { coronavirus } \\ \text { (MERS-CoV) }\end{array} & \begin{array}{c}\text { Phase II study; } \\ \text { Open. }\end{array} \\ & \\ \text { Pneumonia, viral } & \begin{array}{c}\text { Phase I study; } \\ \text { Open. }\end{array}\end{array}$

Pneumonia, viral

Phase II study; Open.

Pneumonia, viral

\section{Phase I/II study;}

Double-blind;

Placebo-controlled; Randomized.
Treatment

Allogenic adult mesenchymal stem cells from adipose tissue.

Number of Patients

Patients aged 18 years and older with HIV infection $(n=15)$.

UC-MSC, 1.5 x 10E6/kg

intravenously on week $0,4,12$, 24, 36, 48; UC-MSC, $0.5 \mathrm{x}$ $10 \mathrm{E} 6 / \mathrm{kg}$ i.v. on week $0,4,12$, 24, 36, 48; Placebo.

Intravenous injection of cord-blood allogeneic mesenchymal stem cells (CB-MSCs), 100 million MSCs for each subject. Hemodynamic observation was done for $24 \mathrm{~h}$ after treatment.

Human umbilical cord derived mesenchymal stem cells, 1x10E6 cells/kg, via hepatic artery infusion.

Patients will receive infusions of umbilical cord blood mesenchymal stem cells via peripheral veins once a week for 4 or 8 weeks with standard medical treatment against a control group which will receive standard medical treatment alone.

All subjects will receive umbilical Patients aged 18 to 75 years with cord-derived mesenchymal stem cells (UC-MSC) $3.3 \times 10 \mathrm{E}$ cells $/ 50 \mathrm{ml} /$ bag, 3 bags each time. UC-MSC will be infused intravenously on the $1 \mathrm{st}, 3 \mathrm{rd}$, 5 th, and 7 th days after enrollment, 1 time each day.

Patients will receive either autologous adipose derived mesenchymal cells 500,000/kg intravenous along with conventional treatment (experimental) or conventional treatment only (no intervention: untreated).

Patients will receive mesenchymal stem cells (CB-MSCs) iv at dose $1 \times 10 \mathrm{E} 6 / \mathrm{kg}$ in a single dose.

Patients will be randomized into three groups: Group 1 - no Intervention (untreated): patients that will not be on a ventilator $(n=10)$. No extra intervention will be done. Group 2 - sham comparator (saline control): patients that will be on a ventilator and will receive saline injections
Patients aged 18-65 years with HIV infection who were on long-term antiviral therapy $(n=72)$.

Patients aged 18 to 65 years with decompensated cirrhosis due to hepatitis $\mathrm{B}(n=12)$.

Patients aged 18-65 years with HBV-related liver cirrhosis $(n=240)$.

Patients aged 18-65 years with acute-on-chronic liver failure $(n=261)$. pneumonia with Middle East respiratory syndrome coronavirus (MERS-CoV) $(n=10)$.

Patients aged 18 to 90 years with viral pneumonia/severe acute respiratory syndrome coronavirus 2 (SARS-CoV-2) infection (COVID-19)/respiratory distress $(n=20)$.

Patients aged 18 years and older distress, viral pneumonia due to COVID-19 $(n=10)$.

Patients aged 40-60 years with severe acute respiratory syndrome coronavirus 2 (SARS-CoV-2) infection (COVID-19) and Pneumonia $(n=30)$ with severe acute respiratory 
Table 1 (continued)

\begin{tabular}{llc}
\hline Study Name & Condition & Trial Design \\
\hline & & \\
& & \\
& & \\
Oseltamivir carboxylate in & Pneumonia, viral & Phase I study; \\
COVID-19/viral pneumonia: & & Open; \\
The NCT04371601 study & & Randomized. \\
Ongoing $(5 / 2020)$ &
\end{tabular}

\footnotetext{
AD-MSCs (autologous) in viral pneumonia/severe acute respiratory syndrome coronavirus 2 (SARS-CoV-2) infection (COVID-19)/respiratory distress: The NCT04352803 study

Ongoing (4/2020)

Adipose-derived mesenchymal stem cells in acute respiratory distress syndrome: The NCT01902082 study

\section{Ongoing (7/2013)}

BM-MSCs (allogeneic) in COVID-19 infection/respiratory distress: The NCT04377334 study

Ongoing (5/2020)
}

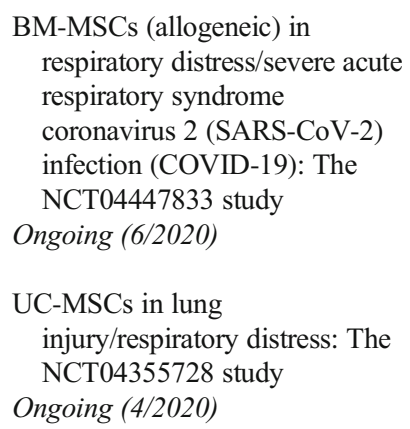

Respiratory distress Phase I study; Open.

Respiratory distress Phase I study; Double-blind; Placebo-controlled; Randomized.

Respiratory distress Phase II study; Open; Randomized.

Respiratory distress Phase I study; Open.

$\begin{array}{rr}\text { Respiratory distress } & \begin{array}{r}\text { Phase I/II study; } \\ \text { Randomized; } \\ \text { Single-blind. }\end{array}\end{array}$

Treatment

$(n=10)$. Group 3: UC-MSCs:

patients that will be on a ventilator and will receive MSC transplantation injections $(\mathrm{n}=10)$.

Patients were randomized to two arms. Experimental arm: patients will receive umbilical cord mesenchymal stem cells at $10 \mathrm{E} 6 / \mathrm{Kg}$ body weight/time, once every 4 days for a total of 4 times. Peripheral intravenous infusion will be given within 3 days of first admission. Control arm: patients will receive conventional symptomatic treatments such as antiviral (oseltamivir), hormones, oxygen therapy, mechanical ventilation and other supportive therapies.

Patients will receive either autologous adipose derived mesenchymal cells 500,000/kg, intravenously, along with conventional treatment (experimental) or conventional treatment only (no intervention/untreated).

Allogeneic adipose-derived mesenchymal stem cells, $1 \mathrm{x}$ 10E6, intravenous; Placebo.

Patients will be randomized into two arms: Arm 1: patients will receive infusion of allogeneic bone marrow-mesenchymal stromal cells (BM-MSCs) (allogeneic). Arm 2: control (untreated).

Patients will be infused with allogeneic bone marrow derived mesenchymal stromal stem cells (BM-MSC). First three patients receive a single dose of 1x10E6 MSC/kg dose, next six patients receive a single dose of 2x10E6 MSC $/ \mathrm{kg}$.

The trial has two groups, each with Patients aged 18 years and older 12 patients $(n=24)$. All eligible patients will be randomized to either the treatment group or standard of care, and randomization will be stratified by ARDS severity. The blinded evaluator will perform clinical efficacy assessments. Subjects will either receive two infusions of UC-MSC in addition to
Patients aged 18 to 70 years with severe acute respiratory syndrome coronavirus 2 (SARS-CoV-2) infection (COVID-19)/viral pneumonia $(n=60)$.

Patients aged 18 to 90 years with viral pneumonia/severe acute respiratory syndrome coronavirus 2 (SARS-CoV-2) infection (COVID-19)/respiratory distress $(n=20)$.

Patients aged 18-90 years with with acute respiratory distress syndrome $(n=20)$.

Patients aged $18 \mathrm{y}$ and older with severe acute respiratory syndrome coronavirus 2 (SARS-CoV-2) infection (COVID-19) induced acute respiratory distress syndrome $(n=40)$.

Patients aged 18-65 years with respiratory distress and severe acute respiratory syndrome coronavirus 2 (SARS-CoV-2) infection (COVID-19) $(n=9)$.

with lung injury/respiratory distress $(n=24)$. 
Table 1 (continued)

\begin{tabular}{|c|c|c|c|c|}
\hline Study Name & Condition & Trial Design & Treatment & Number of Patients \\
\hline & & & $\begin{array}{l}\text { standard of care treatment with } \\
\text { the first infusion administered } \\
\text { within } 24 \mathrm{~h} \text { of study enrollment } \\
\text { and the second infusion } \\
\text { administered within } 72 \mathrm{~h} \text { of } \\
\text { study enrollment (experimental } \\
\text { arm) or standard of care } \\
\text { treatment (control arm). } \\
\text { Subjects in the experimental } \\
\text { arm will receive UC-MSC at } \\
100 \times 10 \mathrm{E} 6 \text { cells/infusion } \\
\text { administered intravenous in } \\
\text { addition to the standard of care } \\
\text { treatment. Subjects in the } \\
\text { control arm will receive } \\
\text { standard of care treatment per } \\
\text { the treating hospital protocol. }\end{array}$ & \\
\hline $\begin{array}{l}\text { CB-MSCs in respiratory distress: } \\
\text { The COVID-19; } \\
\text { NCT04416139 study } \\
\text { Ongoing }(6 / 2020)\end{array}$ & Respiratory distress & $\begin{array}{l}\text { Phase II study; } \\
\text { Open. }\end{array}$ & $\begin{array}{l}\text { Patients will receive cord-blood } \\
\text { mesenchymal stem cells } \\
\text { (CB-MSCs) iv at dose } \\
\text { 1x10E6/kg in a single dose. }\end{array}$ & $\begin{array}{l}\text { Patients aged } 18 \text { y and older with } \\
\text { severe acute respiratory } \\
\text { distress, viral pneumonia due to } \\
\text { COVID-19 }(\mathrm{n}=10) \text {. }\end{array}$ \\
\hline $\begin{array}{l}\text { Double-Blind, Multicenter, Study } \\
\text { to Evaluate the Efficacy of } \\
\text { PLX-PAD for the Treatment of } \\
\text { COVID- } 19 \text {. The } \\
\text { NCT04389450 study } \\
\text { Ongoing }(05 / 2020)\end{array}$ & Respiratory distress & $\begin{array}{l}\text { Double-blind; } \\
\text { Placebo-controll- } \\
\text { ed; Randomized }\end{array}$ & $\begin{array}{l}\text { Mesenchymal stems cells } \\
\text { (PLX-PAD). }\end{array}$ & $\begin{array}{l}\text { Patients aged } 40-80 \text { years } \\
\quad(n=140) .\end{array}$ \\
\hline $\begin{array}{l}\text { Human umbilical cord derived } \\
\text { CD362 positive mesenchymal } \\
\text { stem cells in respiratory } \\
\text { distress: The REALIST; } \\
\text { NCT03042143 study } \\
\text { Ongoing }(2 / 2017)\end{array}$ & Respiratory distress & $\begin{array}{l}\text { Phase I/II study; } \\
\text { Double-blind; } \\
\text { Placebo-controll- } \\
\text { ed; Randomized. }\end{array}$ & $\begin{array}{l}\text { In Japan, investigators used } \\
\text { adipose-derived plastic } \\
\text { adherent cells in patients } \\
(\mathrm{n}=12) \text { with ARDS } \\
\text { randomized } 1: 1 \text { to MSC or } \\
\text { placebo. In the US Matthay has } \\
\text { completed the phase } 1 \text { START } \\
\text { trial, using a dose escalation } \\
\text { study of plastic adherent bone } \\
\text { marrow derived MSC, in } \\
\text { patients with moderate to severe } \\
\text { ARDS. START showed a trend } \\
\text { to reduced lung injury in the } \\
\text { group treated with the highest } \\
\text { (10x10E6cells } / \mathrm{kg} \text { ) compared } \\
\text { with the lower doses } \\
(1-5 \times 10 \mathrm{E} 6 \mathrm{cell} / \mathrm{kg} \text { ). }\end{array}$ & $\begin{array}{l}\text { Patients aged } 16 \text { years and older } \\
\text { with acute respiratory distress } \\
\text { syndrome }(n=75)\end{array}$ \\
\hline $\begin{array}{l}\text { Hydroxychloroquine, } \\
\text { lopinavir/ritonavir, } \\
\text { azithromycin and WJ-MSC in } \\
\text { respiratory distress/COVID 19: } \\
\text { The NCT04390152 study } \\
\text { Ongoing (5/2020) }\end{array}$ & Respiratory distress & $\begin{array}{l}\text { Phase I/II study; } \\
\text { Open; } \\
\text { Placebo-controll- } \\
\text { ed; Randomized. }\end{array}$ & $\begin{array}{l}\text { Patients will be randomized to two } \\
\text { groups: Group } 1 \\
\text { (experimental): WJ MSC } \\
\text { 50x10E6, intravenous, two } \\
\text { doses plus standard treatment } \\
\text { with hydroxychloroquine + } \\
\text { lopinavir + ritonavir plus } \\
\text { azithromycin and ventilation } \\
\text { support. Group } 2 \text { (active - } \\
\text { comparator; control group): } \\
\text { hydroxychloroquine, lopinavir } \\
\text { + ritonavir or azithromycin and } \\
\text { ventilation support plus placebo } \\
\text { (standard therapy). Standard } \\
\text { therapy as per hospital protocol, } \\
\text { hydroxychloroquine } \\
400 \text { mg + lopinavir + ritonavir }\end{array}$ & $\begin{array}{l}\text { Patients aged } 18 \text { to } 80 \text { y with } \\
\text { respiratory distress/COVID-19 } \\
(\mathrm{n}=40) .\end{array}$ \\
\hline
\end{tabular}


Table 1 (continued)

\begin{tabular}{llc}
\hline Study Name & Condition & Trial Design \\
\hline & & \\
& & \\
& & \\
PL-MSC in respiratory stress: The & Respiratory distress & Phase I study; \\
NCT02215811 study & & Open; \\
Ongoing (8/2014) & multi-center; \\
& non-randomized \\
WJ-MSC in & Respiratory distress & Phase I/II study; \\
COVID-19/respiratory distress: & & Double-blind; \\
The STROMA-CoV2; & & Placebo-controll- \\
NCT04333368 study & & ed; Randomized
\end{tabular}

Ongoing (4/2020)
Severe acute respiratory syndrome coronavirus 2 (SARS-CoV-2) infection (COVID-19)

\footnotetext{
AD-MSCs (autologous) in viral pneumonia/severe acute respiratory syndrome coronavirus 2 (SARS-CoV-2) infection (COVID-19)/respiratory distress: The NCT04352803 study

Ongoing (4/2020)

BM-MSCs (allogeneic) in COVID-19 infection/respiratory distress: The NCT04377334 study Ongoing (5/2020)
}

Severe acute respiratory syndrome coronavirus 2 (SARS-CoV-2) infection (COVID-19)

Severe acute respiratory syndrome coronavirus 2 (SARS-CoV-2) infection (COVID-19)
Treatment

Number of Patients
400/100 or azithromycin $500 \mathrm{mg}$ and placebo will be administered.

Patients will be enrolled and receive allogeneic bone marrow-derived mesenchymal stromal cells (BM-MSC).

Patients will be randomized to receive either WJ-MSC (at the dose of 1 million $/ \mathrm{kg}$ ) administered via peripheral or central venous line over 30 to $45 \mathrm{~min}$, using tubing with a 200-microm filter. Cell suspension in a $150 \mathrm{ml}$ volume) or $\mathrm{NaCl} 0.9 \%(150 \mathrm{ml})$, intravenous at day 1, 3 and 5 .

Phase II study; Double-blind; Placebo-controlled; Randomized.

Subjects would receive the following interventions: Arm 1: allogeneic HB-AD-MSCs $200 \mathrm{mM}$ : subjects assigned to this arm would receive five iv infusions of HB-AD-MSCs at 200 million cells/dose. Arm 2: allogeneic HB-adMSCs $100 \mathrm{mM}$ : subjects would receive five iv infusions of HB-AD-MSCs at 100 million cells/dose. Arm 3: allogeneic HB-AD-MSCs $50 \mathrm{mM}$ : subjects would receive five iv infusions of HB-ADMSCs at 200 million cells/dose.

Placebo-comparator arm (placebo): subjects assigned to this arm would receive five iv infusions of placebo intervention (saline). Hope Biosciences allogeneic adipose-derived mesenchymal stem cells would be administered to the subjects in this study. Infusions would occur at weeks $0,2,6,10$, and 14.

Phase I study; Open.

tients will receive either autologous adipose derived mesenchymal cells 500,000/kg iv along with conventional treatment (experimental) or conventional treatment only (no intervention: untreated).

Phase II study; Open;

Randomized.
Patients will be randomized into two arms: Arm 1: patients will receive infusion of bone marrow-mesenchymal stem cells (BM-MSCs) (allogeneic). Arm 2: control: (untreated).
Patients aged 18 years and older with viral-induced acute respiratory distress syndrome (ARDS) $(\mathrm{n}=10)$.

Patients aged 18 years and older with COVID-19/respiratory distress $(n=60)$.

Healthy volunteers aged 18 years and older with severe acute respiratory syndrome coronavirus 2 (SARS-CoV-2) infection (COVID-19) $(n=100)$.
Patients aged 18 to 90 years with viral pneumonia/severe acute respiratory syndrome coronavirus 2 (SARS-CoV-2) infection

(COVID-19)/respiratory distress $(n=20)$.
Patients aged 18 years and older with severe acute respiratory syndrome coronavirus 2 (SARS-CoV-2) infection (COVID-19) induced acute respiratory distress syndrome $(\mathrm{n}=40)$. 
Table 1 (continued)

\begin{tabular}{|c|c|c|c|c|}
\hline Study Name & Condition & Trial Design & Treatment & Number of Patients \\
\hline $\begin{array}{l}\text { BM-MSCs (allogeneic) in } \\
\text { respiratory distress/severe acute } \\
\text { respiratory syndrome } \\
\text { coronavirus } 2 \text { (SARS-CoV-2) } \\
\text { infection (COVID-19): The } \\
\text { NCT04447833 study } \\
\text { Ongoing }(6 / 2020)\end{array}$ & $\begin{array}{l}\text { Severe acute } \\
\quad \text { respiratory } \\
\text { syndrome } \\
\text { coronavirus } 2 \\
\text { (SARS-CoV-2) } \\
\text { infection } \\
\text { (COVID-19) }\end{array}$ & $\begin{array}{l}\text { Phase I study; } \\
\text { Open. }\end{array}$ & $\begin{array}{l}\text { Patients will be infused with } \\
\text { allogeneic bone marrow } \\
\text { derived mesenchymal stromal } \\
\text { stem cells (BM-MSC). First } \\
\text { three patients receive a single } \\
\text { dose of } 1 \times 10 \mathrm{E} 6 \mathrm{MSC} / \mathrm{kg} \text { dose, } \\
\text { next six patients receive a single } \\
\text { dose of } 2 \times 10 \mathrm{E} 6 \mathrm{MSC} / \mathrm{kg} \text {. }\end{array}$ & $\begin{array}{l}\text { Patients aged } 18-65 \text { years with } \\
\text { respiratory distress and severe } \\
\text { acute respiratory syndrome } \\
\text { coronavirus } 2 \text { (SARS-CoV-2) } \\
\text { infection (COVID-19) }(n=9) \text {. }\end{array}$ \\
\hline $\begin{array}{l}\text { BM-MSCs (allogeneic) in severe } \\
\text { acute respiratory syndrome } \\
\text { coronavirus } 2 \text { (SARS-CoV-2) } \\
\text { infection (COVID-19): The } \\
\text { MESCEL-COVID19; } \\
\text { NCT04366271 study } \\
\text { Ongoing (4/2020) }\end{array}$ & $\begin{array}{l}\text { Severe acute } \\
\quad \text { respiratory } \\
\text { syndrome } \\
\text { coronavirus } 2 \\
\text { (SARS-CoV-2) } \\
\text { infection } \\
\text { (COVID-19) }\end{array}$ & $\begin{array}{l}\text { Phase II study; } \\
\text { Multicenter; } \\
\text { Open; } \\
\text { Randomized. }\end{array}$ & $\begin{array}{l}\text { Patients will receive either } \\
\text { infusion of umbilical cord tissue } \\
\text { derived undifferentiated } \\
\text { allogeneic mesenchymal cells } \\
\text { (experimental) or best treatment } \\
\text { option ie, standard of care for } \\
\text { COVID-19 according to } \\
\text { investigator criteria } \\
\text { (active-comparator). }\end{array}$ & $\begin{array}{l}\text { Patients aged } 40-80 \text { years with } \\
\text { severe acute respiratory } \\
\text { syndrome coronavirus } 2 \\
\text { (SARS-CoV-2) infection } \\
\text { (COVID-19) }(n=106) .\end{array}$ \\
\hline $\begin{array}{l}\text { CB-MSCs in } 2019 \text { novel } \\
\text { coronavirus }(2019-\mathrm{nCoV}) \\
\text { infection: The NCT04273646 } \\
\text { study } \\
\text { Ongoing }(2 / 2020)\end{array}$ & $\begin{array}{l}\text { Severe acute } \\
\text { respiratory } \\
\text { syndrome } \\
\text { coronavirus } 2 \\
\text { (SARS-CoV-2) } \\
\text { infection } \\
\text { (COVID-19) }\end{array}$ & $\begin{array}{l}\text { Open; } \\
\text { Placebo-controll- } \\
\text { ed; Randomized. }\end{array}$ & $\begin{array}{l}\text { Patients were randomized to } \\
\text { conventional treatment plus } \\
\text { CB-MSCs four times }(0.5 \mathrm{x} \\
\text { 10E6)/kg body weight } \\
\text { intravenously at day } 1,3,5 \text { and } \\
\text { 7) or conventional treatment } \\
\text { plus placebo. }\end{array}$ & $\begin{array}{l}\text { Patients aged } 18 \text { to } 65 \text { years with } \\
2019 \text { novel coronavirus } \\
(2019-\mathrm{nCoV}) \text { infection } \\
(n=48) .\end{array}$ \\
\hline $\begin{array}{l}\text { CB-MSCs in respiratory distress: } \\
\text { The COVID-19; } \\
\text { NCT04416139 study } \\
\text { Ongoing }(6 / 2020)\end{array}$ & $\begin{array}{l}\text { Severe acute } \\
\quad \text { respiratory } \\
\text { syndrome } \\
\text { coronavirus } 2 \\
\text { (SARS-CoV-2) } \\
\text { infection } \\
\text { (COVID-19) }\end{array}$ & $\begin{array}{l}\text { Phase II study; } \\
\text { Open. }\end{array}$ & $\begin{array}{l}\text { Patients will receive mesenchymal } \\
\text { stem cells (CB-MSCs) } \\
\text { intravenously at dose } \\
1 \times 10 \mathrm{E} 6 / \mathrm{kg} \text { in a single dose. }\end{array}$ & $\begin{array}{l}\text { Patients aged } 18 \text { years and older } \\
\text { with severe acute respiratory } \\
\text { distress, viral pneumonia due t } \\
\text { COVID-19 }(n=10) \text {. }\end{array}$ \\
\hline $\begin{array}{l}\text { MSC in } 2019 \text { novel coronavirus } \\
\text { (2019-nCoV) pneumonia } \\
\text { infection: The NCT04252118 } \\
\text { study } \\
\text { Ongoing }(2 / 2020)\end{array}$ & $\begin{array}{l}\text { Severe acute } \\
\text { respiratory } \\
\text { syndrome } \\
\text { coronavirus } 2 \\
\text { (SARS-CoV-2) } \\
\text { infection } \\
\text { (COVID-19) }\end{array}$ & $\begin{array}{l}\text { Phase I study; } \\
\text { Multicenter; } \\
\text { Open. }\end{array}$ & $\begin{array}{l}\text { All patients will receive the } \\
\text { conventional treatment. This } \\
\text { study consists of two groups: } \\
\text { Group } 1 \text { (experimental MSC } \\
\text { treatment group): conventional } \\
\text { treatment plus MSCs will be } \\
\text { administered. A } 20 \text { patients will } \\
\text { receive conventional treatment } \\
\text { plus three times (one round) of } \\
\text { MSCs ( } 0.5 \text { to } 1.0 \text { x } 10 \mathrm{E} 6 \\
\text { MSCs/kg body weight iv at } \\
\text { days } 0,3 \text { and } 6 \text { ). Group } 2 \text { (no } \\
\text { intervention, conventional } \\
\text { control group): without MSC } \\
\text { therapy, the equal } 20 \text { patients } \\
\text { will receive only conventional } \\
\text { treatment. }\end{array}$ & $\begin{array}{l}\text { Patients aged 18-65 years with } \\
2019 \text { novel coronavirus } \\
(2019-n C o V) \text { pneumonia } \\
\text { infection }(n=40) \text {. }\end{array}$ \\
\hline $\begin{array}{l}\text { Mesenchymal stem cell in } \\
\text { COVID-19: The } \\
\text { NCT04392778 study } \\
\text { Ongoing }(5 / 2020)\end{array}$ & $\begin{array}{l}\text { Severe acute } \\
\quad \text { respiratory } \\
\text { syndrome } \\
\text { coronavirus } 2 \\
\text { (SARS-CoV-2) } \\
\text { infection } \\
\text { (COVID-19) }\end{array}$ & $\begin{array}{l}\text { Phase I/II study; } \\
\text { Double-blind; } \\
\text { Placebo-controll- } \\
\text { ed; Randomized. }\end{array}$ & $\begin{array}{l}\text { Patients will be randomized into } \\
\text { three groups: Group 1: no } \\
\text { Intervention: untreated: patients } \\
\text { that will not be on a ventilator } \\
(\mathrm{n}=10) \text {. No extra intervention } \\
\text { will be done. Group } 2 \text { (sham } \\
\text { comparator, saline control): } \\
\text { patients that will be on a } \\
\text { ventilator and will receive } \\
\text { saline injections ( } \mathrm{n}=10) \text { as } \\
\text { control for MSC transplantation } \\
\text { group. Saline will be given to } \\
\text { patients positively, clinically } \\
\text { and radiologically diagnosed }\end{array}$ & $\begin{array}{l}\text { Patients aged } 40-60 \text { years with } \\
\text { severe acute respiratory } \\
\text { syndrome coronavirus } 2 \\
\text { (SARS-CoV-2) infection } \\
\text { (COVID-19) and Pneumonia } \\
(\mathrm{n}=30)\end{array}$ \\
\hline
\end{tabular}


Table 1 (continued)

\begin{tabular}{|c|c|c|c|c|}
\hline Study Name & Condition & Trial Design & Treatment & Number of Patients \\
\hline $\begin{array}{l}\text { Oseltamivir carboxylate in } \\
\text { COVID-19/viral pneumonia: } \\
\text { The NCT04371601study } \\
\text { Ongoing (5/2020) }\end{array}$ & $\begin{array}{l}\text { Severe acute } \\
\text { respiratory } \\
\text { syndrome } \\
\text { coronavirus } 2 \\
\text { (SARS-CoV-2) } \\
\text { infection } \\
\text { (COVID-19) }\end{array}$ & $\begin{array}{l}\text { Phase I study; } \\
\text { Open; } \\
\text { Randomized. }\end{array}$ & $\begin{array}{l}\text { with COVID-19, followed with } \\
3 \text { months observation. Group 3: } \\
\text { UC-MSCs: patients that will be } \\
\text { on a ventilator and will receive } \\
\text { MSC transplantation injections } \\
\text { ( } \mathrm{n}=10 \text { ). } \\
\text { Patients were randomized to two } \\
\text { arms Experimental arm: } \\
\text { patients received umbilical cord } \\
\text { mesenchymal stem cells at } \\
\text { 106/Kg body weight/time, once } \\
\text { every } 4 \text { days for a total of } 4 \\
\text { times. Peripheral intravenous } \\
\text { infusion was given within } \\
3 \text { days of first admission } \\
\text { Control arm: patients received } \\
\text { conventional symptomatic } \\
\text { treatments such as antiviral } \\
\text { (oseltamivir), hormones, } \\
\text { oxygen therapy, mechanical } \\
\text { ventilation and other supportive } \\
\text { therapies. }\end{array}$ & $\begin{array}{l}\text { Patients aged } 18 \text { to } 70 \text { years with } \\
\text { severe acute respiratory } \\
\text { syndrome coronavirus } 2 \\
\text { (SARS-CoV-2) infection } \\
\text { (COVID-19)/viral pneumonia } \\
(\mathrm{n}=60) \text {. }\end{array}$ \\
\hline $\begin{array}{l}\text { Paracetamol and } \\
\text { diphenhydramine } \\
\text { hydrochloride in COVID-19: } \\
\text { The NCT04345601 study } \\
\text { Ongoing (4/2020) }\end{array}$ & $\begin{array}{l}\text { Severe acute } \\
\quad \text { respiratory } \\
\text { syndrome } \\
\text { coronavirus } 2 \\
\text { (SARS-CoV-2) } \\
\text { infection } \\
\text { (COVID-19) }\end{array}$ & $\begin{array}{l}\text { Phase I study; } \\
\text { Open. }\end{array}$ & $\begin{array}{l}\text { Patients will receive a single } \\
\text { intravenously infusion of } 2 \mathrm{x} \\
10 \mathrm{E} 6 \text { cells } / \mathrm{kg} \text { of mesenchymal } \\
\text { stem cells. }\end{array}$ & $\begin{array}{l}\text { Patients aged } 18 \text { years and older } \\
\text { with severe acute respiratory } \\
\text { syndrome coronavirus } 2 \\
\text { (SARS-CoV-2) infection } \\
\text { (COVID-19) }(\mathrm{n}=30)\end{array}$ \\
\hline $\begin{array}{l}\text { SBI-101 in COVID-19 /acute } \\
\text { renal failure: The } \\
\text { NCT04445220 study } \\
\text { Ongoing }(6 / 2020)\end{array}$ & $\begin{array}{l}\text { Severe acute } \\
\quad \text { respiratory } \\
\text { syndrome } \\
\text { coronavirus } 2 \\
\text { (SARS-CoV-2) } \\
\text { infection } \\
\text { (COVID-19) }\end{array}$ & $\begin{array}{l}\text { Phase I/ II study; } \\
\text { Double-blind; } \\
\text { Placebo-controll- } \\
\text { ed; Randomized. }\end{array}$ & $\begin{array}{l}\text { Patients will be randomized to } \\
\text { SBI-101 device containing } \\
\text { allogeneic human } \\
\text { mesenchymal stromal cells } \\
\text { (MSCs) at low ( } 250 \text { million } \\
\text { MSCs) or high ( } 750 \text { million } \\
\text { MSCs) or sham control } \\
\text { containing no MSCs. }\end{array}$ & $\begin{array}{l}\text { Patients aged } 18 \text { years and older } \\
\text { with COVID-19/acute renal } \\
\text { failure }(n=24)\end{array}$ \\
\hline
\end{tabular}

We may conclude from these analyses that despite many pre-clinical studies reviewed here, MSCs were not widely applied for treatment of patients with viral diseases/ infections in the last years. The emergent COVID-19 and perspective of new viral pandemics may pave the way for new studies, investments in this field and development of platforms for production of therapeutic MSCs for these applications.

\section{Future Directions of MSC-Based Therapies for COVID-19 and Other Viral Diseases}

As reviewed here, the benefits of MSC-based therapy in viral infections are based on their immunomodulatory, anti-inflammatory, antiviral, anti-infective, anti-apoptotic, anti-fibrotic, and angiogenic properties [3, 4, 9, 10, 113].
A cellular product to be used for viral disease therapy must have anti-inflammatory and antiviral properties but it cannot suppress patients when dealing with the present infection and/or make them susceptible to other infections $[4,111]$. In this scenario, MSCs have many advantages, because they have these abilities to fight against viral infections, beyond their smart and flexible immunomodulatory and regenerative abilities [8, 9].

To date, as previously discussed, the available data regarding MSC administration in pre-clinical and clinical viral infections are still scarce and inconsistent in the literature. Preclinical models of acute lung injury, acute respiratory distress syndrome (ARDS), viral hepatitis, HIV infection, and viral pneumonia have been evaluated in the last years [87, $111,112,114]$. The safety of this MSC-based therapy has also been demonstrated in early-stage clinical studies, although in relatively small patient cohorts with different MSC sources and study designs [87, 111, 112, 114]. 

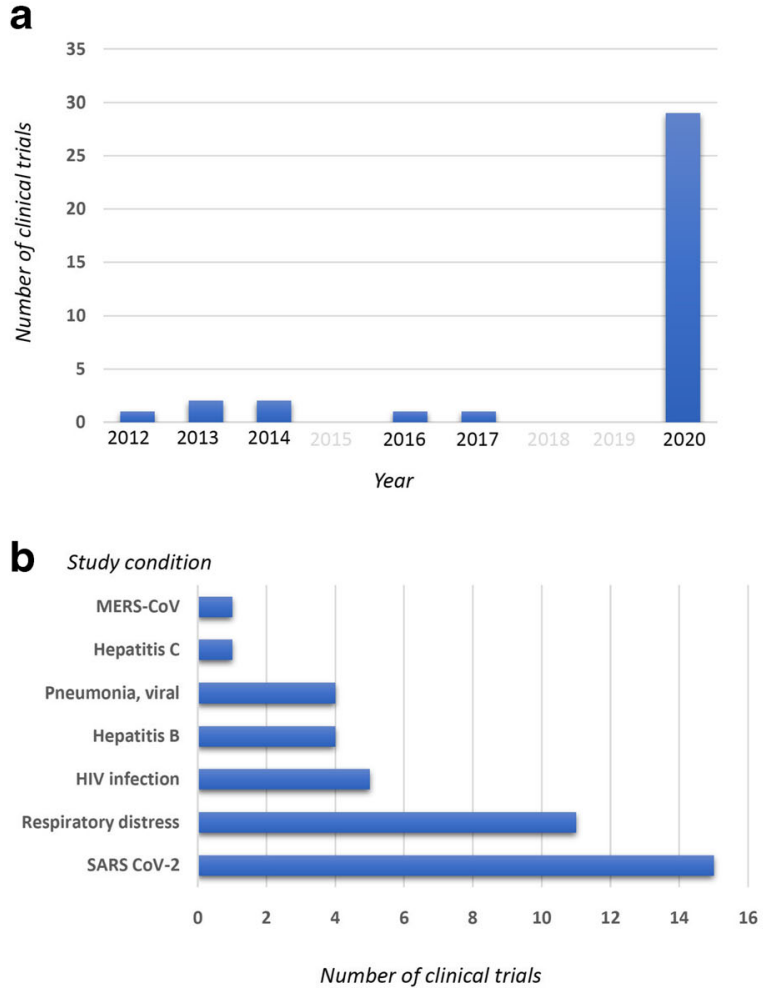

Fig. 5 Ongoing MSC-based clinical trials for viral infections. (a). The start year of the clinical trials; (b). The viral infectious diseases currently being treated with MSCs; (c). Current development phase of the clinical

To date there are no established priming/preconditioning protocols designed to improve the therapeutic effect of MSCs to target viral infections $[115,116]$. Some approaches have been reported only to boost the antimicrobial properties of MSCs [113].

Notably, hypoxia priming of MSCs induces autophagy [117], increases microvesicles and growth factors release $[118,119]$, upregulates chemokine-receptors expression, decreases cellular senescence and apoptosis, and promotes higher retention in vivo and greater therapeutic efficacy [120]. Therefore, new strategies to improve antiviral MSC properties should be developed for production of more robust MSC-based products to treat patients with viral infection diseases, including COVID-19 [116, 121, 122].

Nowadays, the COVID-19 pandemic represents a public health emergency and has prompted an urgent need for novel or alternative therapies [5, 103, 105, 123-127]. Almost every patient with COVID-19 presents with lung involvement, whereas severe complications, such as ARDS, are only observed in a subgroup of severe patients. An excessive inflammatory response to SARS-CoV-2 is thought to be a major cause of disease severity and death in patients with COVID19 [128].

In this context, MSC-based therapy would be plausible, because they are easily available and expanded from allogeneic tissue source, they may be previously cryopreserved and

\section{C}

Development phases
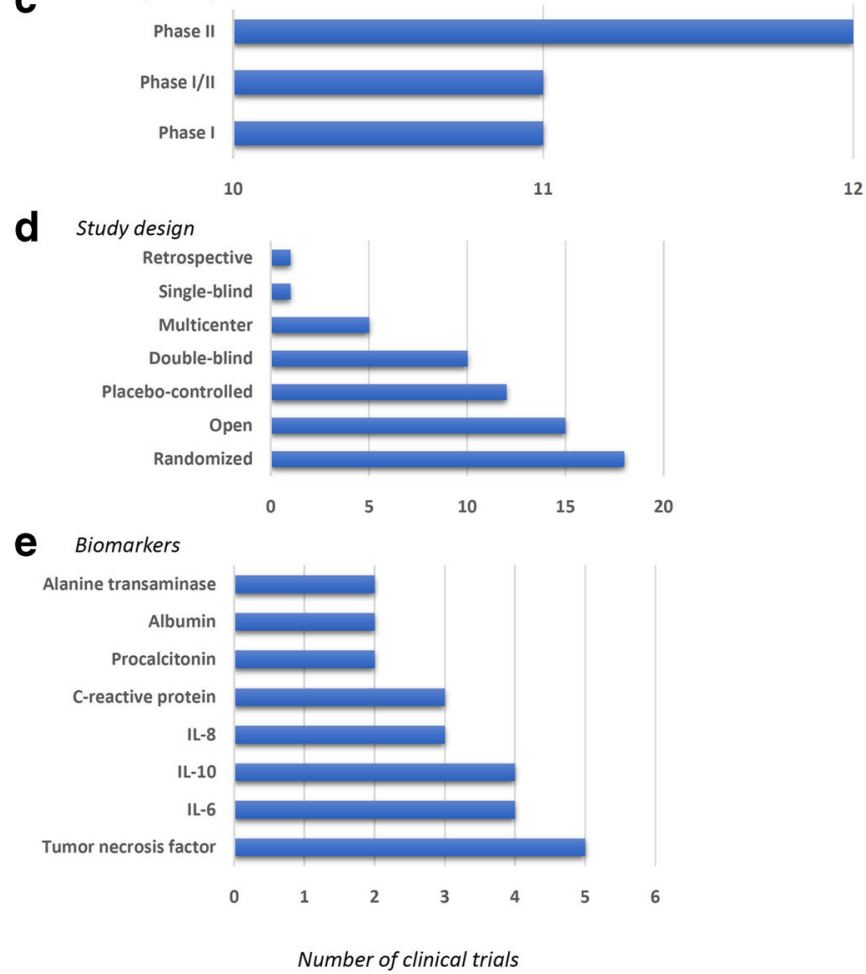

trial; (d). Clinical study design; E. The top 10 biomarkers used in the MSC-based clinical trials. Data extracted from the Integrity Clarivate database (searched on July 6th, 2020)

available "off the shelf" and easily intravenously infused. The remarkable immunomodulatory and regenerative abilities of MSCs may be effective for attenuating the cytokine storm and preventing progression to ARDS and multiple organ failure in severe COVID-19 patients [5, 103, 105, 123-125, 127, 129]. In addition, intravenously infused MSCs become trapped in the lung. In the case of COVID-19, this fact may be beneficial as the lung is the primary organ affected by SARS-CoV-2 [5, $103,105,123-127]$.

Nevertheless, any consideration of MSC-based therapy for COVID-19 should be focused on very severe/critical cases characterized by decontrolled immune response, and critical ARDS and systemic organ involvement $[5,123,127]$. We strongly argue that MSCs should not be infused during the early period of viral infection, where inflammation is very important and beneficial to contain viral infection. If wrongly used MSCs could act as a double-edged sword, since too much immunosuppression can abolish the "physiological inflammation" necessary to control viral infection and replication inflammation is necessary to deal with virus [103].

Moreover, several challenges still have to be addressed, especially MSC dosing and timing of administration, since an exacerbated immunosuppression may have the reverse effect $[5,103,105,123-127]$. The MSC-based clinical trials should be carefully designed (randomized; placebocontrolled; large patient cohorts) to ensure that the results will 
be effective, accurate, trustworthy and significant. Besides, these trials must also be conducted under appropriate regulatory supervision and standards, and the results should be reported in a complete and transparent manner.

Ethical guidelines provided by the World Health Organization (WHO), which are applicable to cell-based clinical trials, must also be followed for MSC-based therapies for COVID-19. Ethical and moral aspects should be complied as it would be in non-pandemic situations. In addition, the possible risks be reasonable in relation to expected therapeutic benefits of MSC infusions [130].

A very recent position review from research leaders of the International Society of Cellular and Gene Therapies (ISCT) has considered that there may be a potential role for MSCbased therapy in COVID-19, however, rationally designed and controlled clinical approaches are needed to demonstrate accurately its safety and therapeutic efficacy [131].

In conclusion, the perspective of treating viral infection diseases, including COVID-19 and other emergent respiratory tract viral infections, with MSCs may be promising. However, strict patient inclusion/exclusion criteria should be defined, well-designed and controlled clinical trial should be performed and rigorous ethical considerations must ensure patient safety [5, 106, 107, 130, 131]. Moreover, development of priming protocols to improve MSC quality attributes for clinical application in viral infections should be considered [103, 105, 122]. Finally, rationale and evidence-based MSC therapies for viral infection diseases should be developed, as well as a robust and consistent platform for production of therapeutic MSCs for these applications.

Acknowledgments We thank Andy Cummings for the language review.

Funding/Support This study was financed by two Brazilian foundations: São Paulo Research Foundation (Center for Cell-Based Research, CTC-CEPID-FAPESP, Process number 2013/08135-2) and the Coordination for the Improvement of Higher Education Personnel (CAPES; Finance Code 001).

Authorship Contributions Review concept and design: KCRM. Literature search: JLMR, WCFO, NCN, NCDS.

Data acquisition from public database bank and data analysis: VPC.

Drafting of the manuscript: JLMR, WCFO, NCN, NCDS, DTC, VPC, KS, KCRM.

Critical revision of the manuscript: DTC, KS, KCR.

\section{Compliance with Ethical Standards}

Conflict of Interest Disclosures The authors declare that they have no conflict of interest.

\section{References}

1. Aziz, J., Liao, G., Adams, Z., Rizk, M., Shorr, R., \& Allan, D. S. (2019). Systematic review of controlled clinical studies using umbilical cord blood for regenerative therapy: Identifying barriers to assessing efficacy. Cytotherapy, 21, 1112-1121. https://doi.org/ 10.1016/j.jcyt.2019.08.004.

2. Ahmadi, A. R., Chicco, M., Huang, J., Qi, L., Burdick, J., Williams, G. M., et al. (2019). Stem cells in burn wound healing: A systematic review of the literature. Burns, 45, 1014-1023. https://doi.org/10.1016/j.burns.2018.10.017.

3. Pittenger, M, F., Discher, D, E., Péault, B, M., Phinney, D, G., Hare, J, M., \& Caplan, A, I. (2019). Mesenchymal stem cell perspective: Cell biology to clinical progress. Npj Regenerative Medicine, Vol. 4. doi: https://doi.org/10.1038/s41536-019-00836.

4. Martin, I., Galipeau, J., Kessler, C., Le Blanc, K., \& Dazzi, F. (2019). Challenges for mesenchymal stromal cell therapies. Science Translational Medicine, 11(480). https://doi.org/10. 1126/scitranslmed.aat2189.

5. Khoury, M., Cuenca, J., Cruz, F, F., Figueroa, F, E., Rocco, P, R, M., \& Weiss, D, J. (2020). Current status of cell-based therapies for respiratory virus infections: Applicability to COVID-19. The European Respiratory Journal, Vol. 55. doi: https://doi.org/10. 1183/13993003.00858-2020.

6. Friedenstein, A, J., Chailakhjan, R, K., \& Lalykina, K, S. (1970). The development of fibroblast colonies in monolayer cultures of Guinea-pig bone marrow and spleen cells. Cell Proliferation. doi: https://doi.org/10.1111/j.1365-2184.1970.tb00347.x.

7. Bianco, P., Cao, X., Frenette, P. S., Mao, J. J., Robey, P. G., Simmons, P. J., \& Wang, C. Y. (2013). The meaning, the sense and the significance: Translating the science of mesenchymal stem cells into medicine. Nature Medicine, 19, 35-42. https://doi.org/ 10.1038/nm.3028.

8. Wang, Y., Chen, X., Cao, W., \& Shi, Y. (2014). Plasticity of mesenchymal stem cells in immunomodulation: Pathological and therapeutic implications. Nature Immunology doi: https:// doi.org/10.1038/ni.3002.

9. Shi, Y., Wang, Y., Li, Q., Liu, K., Hou, J., Shao, C., \& Wang, Y. (2018). Immunoregulatory mechanisms of mesenchymal stem and stromal cells in inflammatory diseases. Nature Reviews Nephrology, 14, 493-507. https://doi.org/10.1038/s41581-0180023-5.

10. Naji, A., Eitoku, M., Favier, B., Deschaseaux, F., Rouas-Freiss, N., \& Suganuma, N. (2019). Biological functions of mesenchymal stem cells and clinical implications. Cellular and Molecular Life Sciences, 76, 3323-3348. https://doi.org/10.1007/s00018-01903125-1.

11. Hass, R., Kasper, C., Böhm, S., \& Jacobs, R. (2011). Different populations and sources of human mesenchymal stem cells (MSC): A comparison of adult and neonatal tissue-derived MSC. Cell Communication and Signaling. doi: https://doi.org/ 10.1186/1478-811X-9-12.

12. Kehl, D., Generali, M., Mallone, A., Heller, M., Uldry, A. C., Cheng, P., ... Weber, B. (2019). Proteomic analysis of human mesenchymal stromal cell secretomes: A systematic comparison of the angiogenic potential. Npj Regenerative Medicine, 4(1). doi: https://doi.org/10.1038/s41536-019-0070-y.

13. Fajardo-Orduña, G, R., Mayani, H., \& Montesinos, J, J. (2015). Hematopoietic support capacity of mesenchymal stem cells: Biology and clinical potential. Archives of Medical Research doi: https://doi.org/10.1016/j.arcmed.2015.10.001.

14. Leyendecker, A., Pinheiro, C, C, G., Amano, M, T., \& Bueno, D, F. (2018). The use of human mesenchymal stem cells as therapeutic agents for the in vivo treatment of immune-related diseases: A systematic review. Frontiers in Immunology, 9(SEP). doi: https:// doi.org/10.3389/fimmu.2018.02056.

15. Zhou, Y., Yamamoto, Y., Xiao, Z., \& Ochiya, T. (2019). The immunomodulatory functions of mesenchymal stromal/stem cells 
mediated via paracrine activity. Journal of Clinical Medicine, 8(7), 1025. https://doi.org/10.3390/jcm8071025.

16. da Silva Meirelles, L., Fontes, A, M., Covas, D, T., \& Caplan, A, I. (2009). Mechanisms involved in the therapeutic properties of mesenchymal stem cells. Cytokine and Growth Factor Reviews. doi: https://doi.org/10.1016/j.cytogfr.2009.10.002.

17. Chen, K., Wang, D., Du, W. T., Han, Z. B., Ren, H., Chi, Y., et al. (2010). Human umbilical cord mesenchymal stem cells hUCMSCs exert immunosuppressive activities through a PGE2dependent mechanism. Clinical Immunology, 135(3), 448-458. https://doi.org/10.1016/j.clim.2010.01.015.

18. Vasandan, A, B., Jahnavi, S., Shashank, C., Prasad, P., Kumar, A., \& Jyothi Prasanna, S. (2016). Human mesenchymal stem cells program macrophage plasticity by altering their metabolic status via a PGE 2 -dependent mechanism. Scientific Reports, 6. doi: https://doi.org/10.1038/srep38308.

19. Hyvärinen, K., Holopainen, M., Skirdenko, V., Ruhanen, H., Lehenkari, P., Korhonen, M., ... Kerkelä, E. (2018). Mesenchymal stromal cells and their extracellular vesicles enhance the anti-inflammatory phenotype of regulatory macrophages by downregulating the production of interleukin (IL)-23 and IL-22. Frontiers in Immunology, 9(APR). doi: https://doi.org/ 10.3389/fimmu.2018.00771.

20. Cheung, T. S., Galleu, A., Von Bonin, M., Bornhäuser, M., \& Dazzi, F. (2019). Apoptotic mesenchymal stromal cells induce prostaglandin E2 in monocytes: Implications for the monitoring of mesenchymal stromal cell activity. Haematologica, 104, E438E441. https://doi.org/10.3324/haematol.2018.214767.

21. Abumaree, M. H., Al Jumah, M. A., Kalionis, B., Jawdat, D., Al Khaldi, A., Abomaray, F. M., et al. (2013). Human placental mesenchymal stem cells (pMSCs) play a role as immune suppressive cells by shifting macrophage differentiation from inflammatory M1 to anti-inflammatory M2 macrophages. Stem Cell Reviews and Reports, 9(5), 620-641. https://doi.org/10.1007/s12015-0139455-2.

22. Morrison, T. J., Jackson, M. V., Cunningham, E. K., Kissenpfennig, A., McAuley, D. F., O'Kane, C. M., \& Krasnodembskaya, A. D. (2017). Mesenchymal stromal cells modulate macrophages in clinically relevant lung injury models by extracellular vesicle mitochondrial transfer. American Journal of Respiratory and Critical Care Medicine, 196(10), 1275-1286. https://doi.org/10.1164/rccm.201701-0170OC.

23. Cheung, T. S., \& Dazzi, F. (2018). Mesenchymal-myeloid interaction in the regulation of immunity. Seminars in Immunology, 35, 59-68. https://doi.org/10.1016/j.smim.2018.01.002.

24. Hayaishi, O. (1976). Properties and Function of Indoleamine 2, 3Dioxygenase1. The Journal of Biochemistry, 79(4), 13-21. https:// doi.org/10.1093/oxfordjournals.jbchem.a131115.

25. Qian, F., Villella, J., Wallace, P. K., Mhawech-Fauceglia, P., Tario, J. D., Andrews, C., et al. (2009). Efficacy of levo-1methyl tryptophan and dextro-1-methyl tryptophan in reversing indoleamine-2,3-dioxygenase-mediated arrest of T-cell proliferation in human epithelial ovarian cancer. Cancer Research, 69(13), 5498-5504. https://doi.org/10.1158/0008-5472.CAN-08-2106.

26. Cesario, A., Rocca, B., \& Rutella, S. (2012). The interplay between Indoleamine 2,3-dioxygenase 1 (IDO1) and cyclooxygenase (COX)-2 in chronic inflammation and Cancer. Current Medicinal Chemistry, 18(15), 2263-2271. https://doi.org/10. 2174/092986711795656063.

27. Li, D., Han, Y., Zhuang, Y., Fu, J., Liu, H., Shi, Q., \& Ju, X. (2015). Overexpression of COX-2 but not indoleamine 2,3dioxygenase-1 enhances the immunosuppressive ability of human umbilical cord-derived mesenchymal stem cells. International Journal of Molecular Medicine, 35(5), 1309-1316. https://doi. org/10.3892/ijmm.2015.2137.
28. Wang, Guan, Cao, K., Liu, K., Xue, Y., Roberts, A, I., Li, F., ... Shi, Y. (2018). Kynurenic acid, an IDO metabolite, controls TSG6-mediated immunosuppression of human mesenchymal stem cells. Cell Death and Differentiation. doi: https://doi.org/10. 1038/s41418-017-0006-2.

29. Choi, H., Lee, R. H., Bazhanov, N., Oh, J. Y., \& Prockop, D. J. (2011). Anti-inflammatory protein TSG-6 secreted by activated MSCs attenuates zymosan-induced mouse peritonitis by decreasing TLR2/NF- $\mathrm{KB}$ signaling in resident macrophages. Blood, 118(2), 330-338. https://doi.org/10.1182/blood-2010-12-327353.

30. Liu, Y., Yin, Z., Zhang, R., Yan, K., Chen, L., Chen, F., et al. (2014). MSCs inhibit bone marrow-derived DC maturation and function through the release of TSG-6. Biochemical and Biophysical Research Communications, 450(4), 1409-1415. https://doi.org/10.1016/j.bbrc.2014.07.001.

31. Jiang, X. X., Zhang, Y., Liu, B., Zhang, S. X., Wu, Y., Yu, X. D., \& Mao, N. (2005). Human mesenchymal stem cells inhibit differentiation and function of monocyte-derived dendritic cells. Blood, 105(10), 4120-4126. https://doi.org/10.1182/blood-2004-020586.

32. Nauta, A. J., Kruisselbrink, A. B., Lurvink, E., Willemze, R., \& Fibbe, W. E. (2006). Mesenchymal stem cells inhibit generation and function of both CD34 + -derived and monocyte-derived dendritic cells. The Journal of Immunology, 177(4), 2080-2087. https://doi.org/10.4049/jimmunol.177.4.2080.

33. Dyer, D. P., Salanga, C. L., Johns, S. C., Valdambrini, E., Fuster, M. M., Milner, C. M., et al. (2016). The anti-inflammatory protein TSG-6 regulates chemokine function by inhibiting chemokine/ glycosaminoglycan interactions. Journal of Biological Chemistry, 291(24), 12627-12640. https://doi.org/10.1074/jbc. M116.720953.

34. Meisel, R., Zibert, A., Laryea, M., Göbel, U., Däubener, W., \& Dilloo, D. (2004). Human bone marrow stromal cells inhibit allogeneic T-cell responses by indoleamine 2,3-dioxygenase-mediated tryptophan degradation. Blood, 103(12), 4619-4621. https:// doi.org/10.1182/blood-2003-11-3909.

35. Ryan, J. M., Barry, F., Murphy, J. M., \& Mahon, B. P. (2007). Interferon- $\gamma$ does not break, but promotes the immunosuppressive capacity of adult human mesenchymal stem cells. Clinical and Experimental Immunology, 149(2), 353-363. https://doi.org/10. 1111/j.1365-2249.2007.03422.x.

36. English, K., Ryan, J. M., Tobin, L., Murphy, M. J., Barry, F. P., \& Mahon, B. P. (2009). Cell contact, prostaglandin E2 and transforming growth factor beta 1 play non-redundant roles in human mesenchymal stem cell induction of CD4+ CD25Highforkhead box P3+ regulatory T cells. Clinical and Experimental Immunology, 156(1), 149-160. https://doi.org/10. 1111/j.1365-2249.2009.03874.x.

37. Luz-Crawford, P., Kurte, M., Bravo-Alegría, J., Contreras, R., Nova-Lamperti, E., Tejedor, G., ... Carrión, F. (2013). Mesenchymal stem cells generate a CD4+CD25+Foxp3 + regulatory $\mathrm{T}$ cell population during the differentiation process of Th1 and Th17 cells. Stem Cell Research and Therapy, 4(3). doi: https:// doi.org/10.1186/scrt216.

38. Teklemariam, T., Purandare, B., Zhao, L., \& Hantash, B. M. (2014). Inhibition of DNA methylation enhances HLA-G expression in human mesenchymal stem cells. Biochemical and Biophysical Research Communications, 452(3), 753-759. https://doi.org/10.1016/j.bbrc.2014.08.152.

39. Akiyama, K., Chen, C., Wang, D., Xu, X., Qu, C., Yamaza, T., et al. (2012). Mesenchymal-stem-cell-induced immunoregulation involves FAS-ligand-/FAS-mediated T cell apoptosis. Cell Stem Cell, 10(5), 544-555. https://doi.org/10.1016/j.stem.2012.03.007.

40. Selmani, Z., Naji, A., Zidi, I., Favier, B., Gaiffe, E., Obert, L., et al. (2008). Human leukocyte antigen-G5 secretion by human mesenchymal stem cells is required to suppress T lymphocyte and 
natural killer function and to induce CD4 + CD25 high FOXP3 + regulatory T cells. Stem Cells, 26(1), 212-222. https://doi.org/10. 1634/stemcells.2007-0554.

41. Du, W. J., Reppel, L., Leger, L., Schenowitz, C., Huselstein, C., Bensoussan, D., et al. (2016). Mesenchymal stem cells derived from human bone marrow and adipose tissue maintain their immunosuppressive properties after Chondrogenic differentiation: Role of HLA-G. Stem Cells and Development, 25(19), 1454 1469. https://doi.org/10.1089/scd.2016.0022.

42. Ding, D. C., Chou, H. L., Chang, Y. H., Hung, W. T., Liu, H. W., \& Chu, T. Y. (2016). Characterization of HLA-G and related immunosuppressive effects in human umbilical cord stromaderived stem cells. Cell Transplantation, 25(2), 217-228. https:// doi.org/10.3727/096368915X688182.

43. Chen, C., Liang, J., Yao, G., Chen, H., Shi, B., Zhang, Z., et al. (2017). Mesenchymal stem cells upregulate Treg cells via sHLA$\mathrm{G}$ in SLE patients. International Immunopharmacology, 44, 234 241. https://doi.org/10.1016/j.intimp.2017.01.024.

44. Paine, A., Eiz-Vesper, B., Blasczyk, R., \& Immenschuh, S. (2010). Signaling to heme oxygenase-1 and its antiinflammatory therapeutic potential. Biochemical Pharmacology, 80, 1895-1903. https://doi.org/10.1016/j.bcp.2010.07.014.

45. Laporte, C., Tubbs, E., Cristante, J., Gauchez, A, S., Pesenti, S., Lamarche, F., ... Lablanche, S. (2019). Human mesenchymal stem cells improve rat islet functionality under cytokine stress with combined upregulation of heme oxygenase- 1 and ferritin. Stem Cell Research and Therapy, 10(1). doi: https://doi.org/10.1186/ s13287-019-1190-4.

46. Jiang, D., Muschhammer, J., Qi, Y., Kügler, A., de Vries, J. C., Saffarzadeh, M., et al. (2016). Suppression of neutrophil-mediated tissue damage-A novel skill of mesenchymal stem cells, Stem Cells., 34(9), 2393-2406. https://doi.org/10.1002/stem.2417.

47. Kerkelä, E., Laitinen, A., Räbinä, J., Valkonen, S., Takatalo, M., Larjo, A., et al. (2016). Adenosinergic immunosuppression by human mesenchymal stromal cells requires co-operation with $\mathrm{T}$ cells. Stem Cells, 34(3), 781-790. https://doi.org/10.1002/stem. 2280.

48. Romieu-Mourez, R., François, M., Boivin, M.-N., Bouchentouf, M., Spaner, D. E., \& Galipeau, J. (2009). Cytokine modulation of TLR expression and activation in mesenchymal stromal cells leads to a Proinflammatory phenotype. The Journal of Immunology, 182(12), 7963-7973. https://doi.org/10.4049/jimmunol.0803864.

49. Ma, S., Xie, N., Li, W., Yuan, B., Shi, Y., \& Wang, Y. (2014). Immunobiology of mesenchymal stem cells. Cell Death and Differentiation, 21, 216-225. https://doi.org/10.1038/cdd.2013. 158 .

50. Colombo, M., Raposo, G., \& Théry, C. (2014). Biogenesis, secretion, and intercellular interactions of exosomes and other extracellular vesicles. Annual Review of Cell and Developmental Biology, 30(1), 255-289. https://doi.org/10.1146/annurev-cellbio-101512122326.

51. Ferreira, J, R., Teixeira, G, Q., Santos, S, G., Barbosa, M, A., Almeida-Porada, G., \& Gonçalves, R, M. (2018). Mesenchymal stromal cell secretome: Influencing therapeutic potential by cellular pre-conditioning. Frontiers in Immunology, Vol. 9. doi: https:// doi.org/10.3389/fimmu.2018.02837.

52. Kaur, S., Abu-Shahba, A. G., Paananen, R. O., Hongisto, H., Hiidenmaa, H., Skottman, H., et al. (2018). Small non-coding RNA landscape of extracellular vesicles from human stem cells. Scientific Reports, 8(1). https://doi.org/10.1038/s41598-01833899-6.

53. Whiteside, T. L. (2018). Exosome and mesenchymal stem cell cross-talk in the tumor microenvironment. Seminars in Immunology, 35, 69-79. https://doi.org/10.1016/j.smim.2017.12. 003 .
54. Androulidaki, A., Iliopoulos, D., Arranz, A., Doxaki, C., Schworer, S., Zacharioudaki, V., et al. (2009). The kinase Akt1 controls macrophage response to lipopolysaccharide by regulating MicroRNAs. Immunity, 31(2), 220-231. https://doi.org/10.1016/ j.immuni.2009.06.024.

55. Kumar, M., Ahmad, T., Sharma, A., Mabalirajan, U., Kulshreshtha, A., Agrawal, A., \& Ghosh, B. (2011). Let-7 microRNA-mediated regulation of IL-13 and allergic airway inflammation. Journal of Allergy and Clinical Immunology, 128(5). https://doi.org/10.1016/j.jaci.2011.04.034.

56. Schulte, L. N., Eulalio, A., Mollenkopf, H. J., Reinhardt, R., \& Vogel, J. (2011). Analysis of the host microRNA response to Salmonella uncovers the control of major cytokines by the let-7 family. EMBO Journal, 30(10), 1977-1989. https://doi.org/10. 1038/emboj.2011.94.

57. Yang, L., Boldin, M. P., Yu, Y., Liu, C. S., Ea, C. K., Ramakrishnan, P., et al. (2012). miR-146a controls the resolution of $\mathrm{T}$ cell responses in mice. Journal of Experimental Medicine, 209(9), 1655-1670. https://doi.org/10.1084/jem.20112218.

58. Hart, M., Walch-Rückheim, B., Friedmann, K, S., Rheinheimer, S., Tänzer, T., Glombitza, B., ... Meese, E. (2019). miR-34a: A new player in the regulation of $\mathrm{T}$ cell function by modulation of NF-KB signaling. Cell Death and Disease, 10(2). doi: https://doi. org/10.1038/s41419-018-1295-1.

59. Hillman, Y., Mazkereth, N., Farberov, L., Shomron, N., \& Fishelson, Z. (2016). Regulation of complement-dependent cytotoxicity by MicroRNAs miR-200b, miR-200c, and miR-217. The Journal of Immunology, 196(12), 5156-5165. https://doi.org/10. 4049/jimmunol.1502701.

60. Kong, P., Xie, X., Li, F., Liu, Y., \& Lu, Y. (2013). Placenta mesenchymal stem cell accelerates wound healing by enhancing angiogenesis in diabetic Goto-Kakizaki (GK) rats. Biochemical and Biophysical Research Communications. doi: https://doi.org/ 10.1016/j.bbrc.2013.07.088.

61. Bai, L., Li, D., Li, J., Luo, Z., Yu, S., Cao, S., ... Ma, X. (2016). Bioactive molecules derived from umbilical cord mesenchymal stem cells. Acta Histochemica. doi: https://doi.org/10.1016/j. acthis.2016.09.006.

62. Tao H, Han Z, Han Z, C \& Li Z. (2016). Proangiogenic features of mesenchymal stem cells and their therapeutic applications. Stem Cells International, 2016. doi: https://doi.org/10.1155/2016/ 1314709

63. Corliss, B. A., Azimi, M. S., Munson, J. M., Peirce, S. M., \& Murfee, W. L. (2016). Macrophages: An inflammatory link between angiogenesis and Lymphangiogenesis. Microcirculation, 23(2), 95-121. https://doi.org/10.1111/micc.12259.

64. Motegi, S. i., \& Ishikawa, O. (2017). Mesenchymal stem cells: The roles and functions in cutaneous wound healing and tumor growth. Journal of Dermatological Science, 86, 83-89. https:// doi.org/10.1016/j.jdermsci.2016.11.005.

65. Kachgal, S., \& Putnam, A. J. (2011). Mesenchymal stem cells from adipose and bone marrow promote angiogenesis via distinct cytokine and protease expression mechanisms. Angiogenesis, 14(1), 47-59. https://doi.org/10.1007/s10456-010-9194-9.

66. Jeon, Y. K., Jang, Y. H., Yoo, D. R., Kim, S. N., Lee, S. K., \& Nam, M. J. (2010). Mesenchymal stem cells' interaction with skin: Wound-healing effect on fibroblast cells and skin tissue. Wound Repair and Regeneration, 18(6), 655-661. https://doi.org/10. 1111/j.1524-475X.2010.00636.x.

67. Bailey, C. C., Zhong, G., Huang, I.-C., \& Farzan, M. (2014). IFITM-family proteins: The Cell's first line of antiviral defense. Annual Review of Virology, 1(1), 261-283. https://doi.org/10. 1146/annurev-virology-031413-085537.

68. Schoggins, J. W. (2019). Interferon-stimulated genes: What do they all do? Annual Review of Virology, 6(1), 567-584. https:// doi.org/10.1146/annurev-virology-092818-015756. 
69. Wu, X., Dao Thi, V. L., Huang, Y., Billerbeck, E., Saha, D., Hoffmann, H. H., et al. (2018). Intrinsic Immunity Shapes Viral Resistance of Stem Cells. Cell, 172(3), 423-438.e25. https://doi. org/10.1016/j.cell.2017.11.018.

70. Kane, M., Zang, T. M., Rihn, S. J., Zhang, F., Kueck, T., Alim, M., et al. (2016). Identification of interferon-stimulated genes with antiretroviral activity. Cell Host and Microbe, 20(3), 392-405. https://doi.org/10.1016/j.chom.2016.08.005.

71. Obojes, K., Andres, O., Kim, K. S., Däubener, W., \& SchneiderSchaulies, J. (2005). Indoleamine 2,3-dioxygenase mediates cell type-specific anti-measles virus activity of gamma interferon. Journal of Virology, 79(12), 7768-7776. https://doi.org/10.1128/ jvi.79.12.7768-7776.2005.

72. Mao, R., Zhang, J., Jiang, D., Cai, D., Levy, J. M., Cuconati, A., et al. (2011). Indoleamine 2,3-dioxygenase mediates the antiviral effect of gamma interferon against hepatitis B virus in human hepatocyte-derived cells. Journal of Virology, 85(2), 1048-1057. https://doi.org/10.1128/jvi.01998-10.

73. Meisel, R., Brockers, S., Heseler, K., Degistirici, O., Bülle, H., Woite, C., ... Däubener, W. (2011). Human but not murine multipotent mesenchymal stromal cells exhibit broad-spectrum antimicrobial effector function mediated by indoleamine 2,3dioxygenase. Leukemia : Official Journal of the Leukemia Society of America, Leukemia Research Fund, U.K, 25(4), 648 654. doi: https://doi.org/10.1038/leu.2010.310

74. Qian, X., Xu, C., Fang, S., Zhao, P., Wang, Y., Liu, H., et al. (2016). Exosomal MicroRNAs derived from umbilical mesenchymal stem cells inhibit hepatitis C virus infection. Stem Cells Translational Medicine, 5(9), 1190-1203. https://doi.org/10. 5966/sctm.2015-0348.

75. Gomez-Salazar, M., Gonzalez-Galofre, Z. N., Casamitjana, J., Crisan, M., James, A. W., \& Péault, B. (2020). Five decades later, are mesenchymal stem cells still relevant? Frontiers in Bioengineering and Biotechnology, 8. https://doi.org/10.3389/ fbioe.2020.00148.

76. Budgude, P., Kale, V., \& Vaidya, A. (2020). Mesenchymal stromal cell-derived extracellular vesicles as cell-free biologics for the ex vivo expansion of hematopoietic stem cells. Cell Biology International, 44, 1078-1102. https://doi.org/10.1002/cbin. 11313.

77. Hung, C. F., Mittelsteadt, K. L., Brauer, R., McKinney, B. L., Hallstrand, T. S., Parks, W. C., et al. (2017). Lung pericyte-like cells are functional interstitial immune sentinel cells. American Journal of Physiology - Lung Cellular and Molecular Physiology, 312(4), L556-L567. https://doi.org/10.1152/ajplung. 00349.2016.

78. Hung, C. F., Wilson, C. L., \& Schnapp, L. M. (2019). Pericytes in the lung. In Advances in experimental medicine and biology (Vol. 1122, pp. 41-58). https://doi.org/10.1007/978-3-030-11093-2_3.

79. Leaf, I. A., \& Duffield, J. S. (2017). What can target kidney fibrosis? Nephrology, Dialysis, Transplantation : Official Publication of the European Dialysis and Transplant Association - European Renal Association, 32(1), i89-i97. https://doi.org/10.1093/ndt/ gfw388.

80. Van Linthout, S., Savvatis, K., Miteva, K., Peng, J., Ringe, J., Warstat, K., ... Tschöpe, C. (2011). Mesenchymal stem cells improve murine acute coxsackievirus B3-induced myocarditis. European Heart Journal. doi: https://doi.org/10.1093/eurheartj/ ehq467

81. Klimczak, A., \& Kozlowska, U. (2016). Mesenchymal stromal cells and tissue-specific progenitor cells: Their role in tissue homeostasis. Stem Cells International, 2016, 1-11. https://doi.org/ 10.1155/2016/4285215.

82. Walter, J., Ware, L. B., \& Matthay, M. A. (2014). Mesenchymal stem cells: Mechanisms of potential therapeutic benefit in ARDS and sepsis. The Lancet Respiratory Medicine, 2, 1016-1026. https://doi.org/10.1016/S2213-2600(14)70217-6.

83. McIntyre, L. A., Moher, D., Fergusson, D. A., Sullivan, K. J., Mei, S. H. J., Lalu, M., et al. (2016). Efficacy of mesenchymal stromal cell therapy for acute lung injury in preclinical animal models: A systematic review. PLoS One, 11(1). https://doi.org/10.1371/ journal.pone.0147170.

84. Chan, M. C. W., Kuok, D. I. T., Leung, C. Y. H., Hui, K. P. Y., Valkenburg, S. A., Lau, E. H. Y., et al. (2016). Human mesenchymal stromal cells reduce influenza a H5N1-associated acute lung injury in vitro and in vivo. Proceedings of the National Academy of Sciences of the United States of America, 113(13), 3621-3626. https://doi.org/10.1073/pnas.1601911113.

85. Loy, H., Kuok, D, I, T., Hui, K, P, Y., Choi, M, H, L., Yuen, W., Nicholls, J, M., ... Chan, M, C, W. (2019). Therapeutic implications of human umbilical cord mesenchymal stromal cells in attenuating influenza a(H5N1) virus-associated acute lung injury. Journal of Infectious Diseases. doi: https://doi.org/10.1093/ infdis/jiy478.

86. Qu, M., Yuan, X., Liu, D., Ma, Y., Zhu, J., Cui, J., et al. (2017). Bone marrow-derived mesenchymal stem cells attenuate immunemediated liver injury and compromise virus control during acute hepatitis B virus infection in mice. Stem Cells and Development, 26(11), 818-827. https://doi.org/10.1089/scd.2016.0348.

87. Harrell, C, R., Sadikot, R., Pascual, J., Fellabaum, C., Jankovic, M, G., Jovicik, N.,... Volarevic, V. (2019). Mesenchymal stem cell-based therapy of inflammatory lung diseases: Current understanding and future perspectives. Stem Cells International, 2019. doi: https://doi.org/10.1155/2019/4236973.

88. Liu, S., Peng, D., Qiu, H., Yang, K., Fu, Z., \& Zou, L. (2020). Mesenchymal stem cells as a potential therapy for COVID-19. Stem Cell Research and Therapy, 11. https://doi.org/10.1186/ s13287-020-01678-8.

89. Simonson, O. E., Mougiakakos, D., Heldring, N., Bassi, G., Johansson, H. J., Dalén, M., et al. (2015). In vivo effects of mesenchymal stromal cells in two patients with severe acute respiratory distress syndrome. Stem Cells Translational Medicine, 4(10), 1199-1213. https://doi.org/10.5966/sctm.2015-0021.

90. Xu, L., Gong, Y., Wang, B., Shi, K., Hou, Y., Wang, L., et al. (2014). Randomized trial of autologous bone marrow mesenchymal stem cells transplantation for hepatitis B virus cirrhosis: Regulation of Treg/Th17 cells. Journal of Gastroenterology and Hepatology (Australia), 29(8), 1620-1628. https://doi.org/10. 1111/jgh.12653.

91. Fang, X., Liu, L., Dong, J., Zhang, J., Song, H., Song, Y., et al. (2018). A study about immunomodulatory effect and efficacy and prognosis of human umbilical cord mesenchymal stem cells in patients with chronic hepatitis B-induced decompensated liver cirrhosis. Journal of Gastroenterology and Hepatology (Australia), 33(4), 774-780. https://doi.org/10.1111/jgh.14081.

92. Li, Y. H., Xu, Y., Wu, H. M., Yang, J., Yang, L. H., \& Yue-Meng, W. (2016). Umbilical cord-derived mesenchymal stem cell transplantation in hepatitis B virus related acute-on-chronic liver failure treated with plasma exchange and Entecavir: A 24-month prospective study. Stem Cell Reviews and Reports, 12(6), 645-653. https://doi.org/10.1007/s12015-016-9683-3.

93. Lin, B. L., Chen, J. F., Qiu, W. H., Wang, K. W., Xie, D. Y., Chen, X. Y., et al. (2017). Allogeneic bone marrow-derived mesenchymal stromal cells for hepatitis B virus-related acute-on-chronic liver failure: A randomized controlled trial. Hepatology, 66(1), 209-219. https://doi.org/10.1002/hep.29189.

94. Sveiven, S, N., \& Nordgren, T, M. (2020). Lung-resident mesenchymal stromal cells are tissue-specific regulators of lung homeostasis. American Journal of Physiology-Lung Cellular and Molecular Physiology. doi: https://doi.org/10.1152/ajplung. 00049.2020 . 
95. Rolandsson Enes, S., Åhrman, E., Palani, A., Hallgren, O., Bjermer, L., Malmström, A., et al. (2017). Quantitative proteomic characterization of lung-MSC and bone marrow-MSC using DIAmass spectrometry. Scientific Reports, 7(1), 1-12. https://doi.org/ 10.1038/s41598-017-09127-y.

96. Sinclair, K., Yerkovich, S. T., \& Chambers, D. C. (2013). Mesenchymal stem cells and the lung. Respirology, 18(3), 397411. https://doi.org/10.1111/resp.12050.

97. Foronjy, R. F., \& Majka, S. M. (2012). The potential for resident lung mesenchymal stem cells to promote functional tissue regeneration: Understanding microenvironmental cues. Cells, 1(4), 874-885. https://doi.org/10.3390/cells1040874.

98. Luo, X. Y., Meng, X. J., Cao, D. C., Wang, W., Zhou, K., Li, L., et al. (2019). Transplantation of bone marrow mesenchymal stromal cells attenuates liver fibrosis in mice by regulating macrophage subtypes rocky Tuan; Timothy O'Brien. Stem Cell Research and Therapy, 10(1), 16. https://doi.org/10.1186/ s13287-018-1122-8.

99. Wang, J., Wang, B. J., Yang, J. C., Wang, M. Y., Chen, C., Luo, G. X., \& He, W. F. (2020). Advances in the research of mechanism of pulmonary fibrosis induced by Corona virus disease 2019 and the corresponding therapeutic measures. Zhonghua Shao Shang Za Zhi = Zhonghua Shaoshang Zazhi = Chinese Journal of Burns, 36(0), E006. https://doi.org/10.3760/cma.j.cn50112020200307-00132.

100. Shin, L., \& Peterson, D. A. (2013). Human mesenchymal stem cell grafts enhance Normal and impaired wound healing by recruiting existing endogenous tissue stem/progenitor cells. Stem Cells Translational Medicine, 2(1), 33-42. https://doi.org/10. 5966/sctm.2012-0041.

101. Shetty, A. K. (2020). Mesenchymal stem cell infusion shows promise for combating coronavirus (COVID-19)-induced pneumonia. Aging and Disease, 11, 462-464. https://doi.org/10. 14336/AD.2020.0301.

102. Chen, L., Li, X., Chen, M., Feng, Y., \& Xiong, C. (2020). The ACE2 expression in human heart indicates new potential mechanism of heart injury among patients infected with SARS-CoV-2. Cardiovascular Research doi: https://doi.org/10.1093/cvr/ cvaa078.

103. Golchin, A., Seyedjafari, E., \& Ardeshirylajimi, A. (2020). Mesenchymal stem cell therapy for COVID-19: Present or future. Stem Cell Reviews and Reports, 16, 427-433. https://doi.org/10. 1007/s12015-020-09973-w.

104. Zhang, Y., Ding, J., Ren, S., Wang, W., Yang, Y., Li, S., et al. (2020). Intravenous infusion of human umbilical cord Wharton's jelly-derived mesenchymal stem cells as a potential treatment for patients with COVID-19 pneumonia. Stem Cell Research and Therapy, 11(1), 207. https://doi.org/10.1186/s13287-020-017254.

105. Rajarshi, K., Chatterjee, A., \& Ray, S. (2020). Combating COVID-19 with mesenchymal stem cell therapy. Biotechnology Reports, Vol. 26. doi: https://doi.org/10.1016/j.btre.2020.e00467.

106. Atluri, S., Manchikanti, L., \& Hirsch, J. (2020). A. (2020). Expanded umbilical cord mesenchymal stem cells (UC-MSCs) as a therapeutic strategy in managing critically ILL COVID-19 patients: The case for compassionate use. Pain Physician, 23, E71-E83.

107. Leng, Z., Zhu, R., Hou, W., Feng, Y., Yang, Y., Han, Q., et al. (2020). Transplantation of ACE2- mesenchymal stem cells improves the outcome of patients with covid-19 pneumonia. Aging and Disease, 11(2), 216-228. https://doi.org/10.14336/AD.2020. 0228 .

108. Berlin, D, A., Gulick, R, M., \& Martinez, F, J. (2020). Severe Covid-19. New England Journal of Medicine. doi: https://doi. org/10.1056/nejmcp2009575.
109. Shereen, M. A., Khan, S., Kazmi, A., Bashir, N., \& Siddique, R. (2020). COVID-19 infection: Origin, transmission, and characteristics of human coronaviruses. Journal of Advanced Research, 24, 91-98. https://doi.org/10.1016/j.jare.2020.03.005.

110. South, A. M., Diz, D. I., \& Chappell, M. C. (2020). COVID-19, ACE2, and the cardiovascular consequences. American Journal of Physiology. Heart and Circulatory Physiology, 318(5), H1084H1090. https://doi.org/10.1152/ajpheart.00217.2020.

111. Thanunchai, M., Hongeng, S., \& Thitithanyanont, A. (2015). Mesenchymal stromal cells and viral infection. Stem Cells International. doi: https://doi.org/10.1155/2015/860950.

112. Behnke, J., Kremer, S., Shahzad, T., Chao, C.-M., BöttcherFriebertshäuser, E., Morty, R. E., et al. (2020). MSC based therapies-New perspectives for the injured lung. Journal of Clinical Medicine, 9(3), 682. https://doi.org/10.3390/ jcm9030682.

113. Alcayaga-Miranda, F., Cuenca, J., \& Khoury, M. (2017). Antimicrobial activity of mesenchymal stem cells: Current status and new perspectives of antimicrobial peptide-based therapies. Frontiers in Immunology, Vol. 8. doi: https://doi.org/10.3389/ fimmu.2017.00339.

114. Qin, H., \& Zhao, A. (2020). Mesenchymal stem cell therapy for acute respiratory distress syndrome: From basic to clinics. Protein and Cell. doi: https://doi.org/10.1007/s13238-020-00738-2.

115. Kouroupis, D., Sanjurjo-Rodriguez, C., Jones, E., \& Correa, D. (2019). Mesenchymal stem cell functionalization for enhanced therapeutic applications. Tissue Engineering - Part B: Reviews, 25, 55-77. https://doi.org/10.1089/ten.teb.2018.0118.

116. Noronha, N. de C., Mizukami, A., Caliári-Oliveira, C., Cominal, J. G., Rocha, J. L. M., Covas, D. T., ... Malmegrim, K. C. R. (2019). Correction to: Priming approaches to improve the efficacy of mesenchymal stromal cell-based therapies. Stem Cell Research \& Therapy, 10(1), 132. doi: https://doi.org/10.1186/s13287-0191259-0.

117. Liu, J., Hao, H., Huang, H., Tong, C., Ti, D., Dong, L., ... Fu, X. (2015). Hypoxia regulates the therapeutic potential of mesenchymal stem cells through enhanced autophagy. International Journal of Lower Extremity Wounds. doi: https://doi.org/10.1177/ 1534734615573660

118. Collino, F., Lopes, J, A., Corrêa, S., Abdelhay, E., Takiya, C, M., Wendt, C, H, C., ... Lindoso, R, S. (2019). Adipose-derived mesenchymal stromal cells under hypoxia: Changes in extracellular vesicles secretion and improvement of renal recovery after ischemic injury. Cellular Physiology and Biochemistry. https://oi.org/ 10.33594/000000102

119. Obradovic, H., Krstic, J., Trivanovic, D., Mojsilovic, S., Okic, I., Kukolj, T., et al. (2019). Improving stemness and functional features of mesenchymal stem cells from Wharton's jelly of a human umbilical cord by mimicking the native, low oxygen stem cell niche. Placenta. https://doi.org/10.1016/j.placenta.2019.05.005.

120. Mas-Bargues, C., Sanz-Ros, J., Román-Domínguez, A., Inglés, M., Gimeno-Mallench, L., El Alami, M., ... Borrás, C. (2019). Relevance of oxygen concentration in stem cell culture for regenerative medicine. International Journal of Molecular Sciences, Vol. 20. doi: https://doi.org/10.3390/ijms20051195.

121. Hosseiniyan Khatibi, S, M., Kheyrolahzadeh, K., Barzegari, A., Rahbar Saadat, Y., \& Zununi Vahed, S. (2020). Medicinal signaling cells: A potential antimicrobial drug store. Journal of Cellular Physiology. doi: https://doi.org/10.1002/jcp.29728.

122. Yin, J. Q., Zhu, J., \& Ankrum, J. A. (2019). Manufacturing of primed mesenchymal stromal cells for therapy. Nature Biomedical Engineering, 3, 90-104. https://doi.org/10.1038/ s41551-018-0325-8.

123. Yen, B, L., Yen, M, L., Wang, L, T., Liu, K, J., \& Sytwu, H, K. (2020). Current status of mesenchymal stem cell therapy for immune/inflammatory lung disorders: Gleaning insights for 
possible use in COVID-19. Stem Cells Translational Medicine. doi: https://doi.org/10.1002/sctm.20-0186.

124. Zhao, R. C. (2020). Stem cell-based therapy for coronavirus disease 2019. Stem Cells and Development, 29(11), 679-681. https:// doi.org/10.1089/scd.2020.0071

125. Yu, F., Jia, R., Tang, Y., Liu, J., \& Wei, B. (2020). SARS-CoV-2 infection and stem cells: Interaction and intervention. Stem Cell Research, 46, 101859. https://doi.org/10.1016/j.scr.2020.101859.

126. Du, J., Li, H., Lian, J., Zhu, X., Qiao, L., \& Lin, J. (2020). Stem cell therapy: A potential approach for treatment of influenza virus and coronavirus-induced acute lung injury. Stem Cell Research and Therapy, Vol. 11. doi: https://doi.org/10.1186/s13287-02001699-3.

127. Zumla, A., Wang, F. S., Chang, C., Ippolito, G., Petrosillo, N., Agrati, C., et al. (2020). Reducing mortality and morbidity in patients with severe COVID-19 disease by advancing ongoing trials of mesenchymal stromal (stem) cell (MSC) therapy Achieving global consensus and visibility for cellular hostdirected therapies. International Journal of Infectious Diseases, 96, 431-439. https://doi.org/10.1016/j.ijid.2020.05.040.
128. Zhou, M., Zhang, X., \& Qu, J. (2020). Coronavirus disease 2019 (COVID-19): A clinical update. Frontiers of Medicine, 14, 126 135. https://doi.org/10.1007/s11684-020-0767-8.

129. Chen, X., Shan, Y., Wen, Y., Sun, J., \& Du, H. (2020). Mesenchymal stem cell therapy in severe COVID-19: A retrospective study of short-term treatment efficacy and side effects. Journal of Infection., 116, 1097-1100. https://doi.org/10.1016/j. jinf.2020.05.020.

130. World Health Organization. (2020). Managing ethical issues in infectious disease outbreaks. WHO.

131. Khoury, M., Rocco, P, R, M., Phinney, D, G., Krampera, M., Martin, I., Viswanathan, S., ... Weiss, D, J. (2020). Cell-based therapies for COVID-19: Proper clinical investigations are essential. Cytotherapy. doi: https://doi.org/10.1016/j.jcyt.2020.04.089.

Publisher's Note Springer Nature remains neutral with regard to jurisdictional claims in published maps and institutional affiliations. 